\title{
BAGAIMANA KEDAI KOPI OHAYOU MENINGKATKAN PROSES KEPUTUSAN PEMBELIAN KONSUMEN DI KOTA BANDUNG
}

\author{
Sharon Cabrian \\ Mahasiswa Program Studi Sarjana Ilmu Administrasi Bisnis, Universitas Katolik Parahyangan, Bandung \\ 3216015@student.unpar.ac.id
}

\begin{abstract}
ABSTRAK
Menurut Toffin pada tahun 2019 terjadi peningkatan bisnis kedai kopi sebanyak 3 kali lipat dibandingkan 3 tahun sebelumnya. Adanya kenaikan jumlah kedai kopi menjadi ancaman dan tantangan tersediri bagi para pemilik bisnis kedai kopi. Ohayou Bandung merupakan salah satu kedai kopi yang menghadapi persaingan dalam meningkatnya jumlah kedai kopi di daerah Ciumbuleuit, Bandung. Karena lokasinya yang strategis di mana mahasiswa UNPAR menjadi target marketnya, Ohayou memiliki peluang besar untuk memenuhi permintaan terhadap kopi dan ruang publik. Untuk itu, perusahaan perlu memperhatikan atribut produk yang merupakan salah satu faktor utama yang menjadi pertimbangan konsumen maupun pelanggan dalam keputusan pembelian. Tujuan dari penelitian ini adalah untuk mengetahui apakah atribut produk dan kualitas pelayanan mempengaruhi proses keputusan pembelian di Ohayou Bandung. Variabel atribut produk diukur dengan dimensi kualitas, fitur, desain, merek, dan kemasan. Variabel kualitas pelayanan diukur dengan dimensi kehandalan, daya tanggap, jaminan, empati, dan bukti fisik. Variabel proses pengambilan keputusan pembelian diukur dengan dimensi pengenalan masalah, pencarian informasi, evaluasi alternatif, keputusan pembelian, dan perilaku pasca pembelian. Hasil penelitian menunjukkan bahwa atribut produk dan kualitas pelayanan mempengaruhi keputusan pembelian sebesar 28,7\%. Dalam analisis linear berganda disimpulkan bahwa atribut produk memiliki pengaruh lebih besar terhadap keputusan pembelian dibandingkan kualitas pelayanan. Berdasarkan uji hipotesa parsial, atribut produk berpengaruh secara parsial terhadap keputusan pembelian. Sedangkan kualitas pelayanan tidak berpengaruh secara parsial terhadap keputusan pembelian. Disimpulkan bahwa peningkatan kualitas pelayanan saja tidak cukup untuk meningkatkan keputusan pembelian. Ohayou Bandung disarankan untuk meningkatkan kualitas dan fitur produk, serta meningkatkan penggunaan social media.
\end{abstract}

Kata Kunci: Atribut Produk, Kualitas Pelayanan, Keputusan Pembelian, Ohayou Bandung

\begin{abstract}
According to Toffin, in 2019 there was a 3-fold increase in the coffee shop business compared to the previous 3 years. An increase in the number of coffee shops is a threat and a challenge for coffee shop business owners. Ohayou Bandung is one coffee shop that is facing competition in the increasing number of coffee shops in the Ciumbuleuit area, Bandung. Due to its strategic location where UNPAR students are the target market, Ohayou has a great opportunity to meet the demand for coffee and public spaces. For this reason, companies need to pay attention to product attributes which are one of the main factors that are considered by consumers and customers in purchasing decisions. The purpose of this study was to determine whether product attributes and service quality affect purchasing decisions at Ohayou Bandung. Product attribute variables are measured by the dimensions of quality, features, design, brand, and packaging. Service quality variables are measured by the dimensions of reliability, responsiveness, assurance, empathy, and physical evidence. The variable of the purchasing decision making process is measured by the dimensions of problem recognition, information seeking, evaluation of alternatives, purchasing decisions, and post-purchase behavior. The results showed that the product attributes and service quality influenced purchasing decisions by $28.7 \%$. In multiple linear analysis it is concluded that product attributes have a greater influence on purchasing decisions than service quality. Based on the partial hypothesis test, product attributes partially influence purchasing decisions. Meanwhile, service quality has no partial effect on purchasing decisions. It is concluded that improving service quality alone is not sufficient to improve purchasing decisions. Ohayou Bandung is advised to improve product quality and features, as well as increase the use of social media.
\end{abstract}

Keywords: Product Attributes, Service Quality, Buying Decision, Ohayou Bandung

\section{PENDAHULUAN}

Berdasarkan hasil riset Toffin, diketahui jumlah kedai kopi di Indonesia pada tahun 2019 mencapai angka 2.950, meningkat sebanyak 3x lipat dibandingkan 3 tahun sebelumnya di mana pada tahun 2016 jumlah kedai kopi hanya 1.000 gerai (Sugianto, 2019). Walaupun terjadi peningkatan jumlah kedai kopi yang tinggi, namun jumlah konsumsi kopi hanya meningkat sebanyak 13\% dari tahun 2018 ke 2019 (Sugianto, 2019) . Hal ini menunjukkan tantangan bagi pengusaha 
kopi, di mana peningkatan jumlah kedai kopi, tidak sebanyak meningkatnya jumlah konsumsi kopi sehingga pengusaha kedai kopi perlu memperhatikan factor-faktor penting untuk mempertahankan eksistensinya.

Ohayou merupakan salah satu kedai kopi yang terletak di Jalan Ciumbulueit, Kota Bandung. Konsumen utama Ohayou adalah mahasiswa Universitas Katolik Parahyangan, dikarenakan lokasinya yang sangat dekat dengan universitas tersebut. Meningkatnya persaingan kedai kopi yang cepat juga dialami Ohayou dimana pada tahun 2017 (saat kedai ini berdiri) hanya terdapat 3 kedai kopi lain di sekitar Ciumbuleuit, namun pada akhir tahun 2019 terhitung lebih dari 9 kedai kopi berlokasi di jalan tersebut. Pelaku bisnis menyadari akan prospek yang tinggi pada daerah Ciumbuleuit sehingga menyebabkan adanya persaingan yang semakin ketat.

Menurut wawancara dengan salah satu owner bernama Kenneth, Ohayou berusaha untuk mempertahankan pasar mereka dengan mendengarkan aspirasi dan peka terhadap kebutuhan konsumen sehingga produk dan pelayanan yang disediakan memenuhi kriteria kebutuhan konsumen. Adapun usaha untuk memenuhi kriteria kebutuhan konsumen dilakukan Ohayou melalui peningkatan kualitas bahan baku, fasilitas tempat, dan kinerja karyawan. Selama 3 tahun berjalan, Ohayou selalu melakukan inovasi terhadap varian minuman dan makanannya. Produk Ohayou yang sebagian besar diproduksi dengan resep sendiri sehingga khas dari segi cita rasa menjadi keunikan tersendiri karena tidak bisa didapatkan di kedai kopi lain. Berdasarkan hasil wawancara tersebut diketahui bahwa yang dilakukan oleh pemilk Ohayaou adalah menjaga dan mempertahankan atribut produk dan pelayanan

Untuk meningkatkan eksistensi dan penjualannya, Ohayou perlu memperhatikan faktor yang mempengaruhi keputusan pembelian. Salah satu faktor utama dalam mengambilan keputusan pembelian adalah atribut produk (Nazah, Hartati, \& Siambaton, 2017) dan kualitas pelayanan (Soenawan, Malonda, \& Aprilia, 2015). Adapun untuk itu, dilakukan pra-survey untuk melihat faktor yang menarik bagi konsumen untuk melakukan pembelian di Ohayou Ciumbuleuit. Dalam pra-survey ini, faktor atribut produk dilihat dari cita rasa makanan dan minuman, fasilitas yang tersedia, pamor brand dan keragaman menu. Di samping itu, sikap karyawan, kemudahan transaksi, kecepatan dalam memproses makanan, lokasi yang dekat dengan kampus, dan promo yang menarik digunakan untuk melihat faktor pelayanan.

Tabel 1. Faktor yang menarik bagi konsumen untuk melakukan pembelian di Ohayou Ciumbuleuit

\begin{tabular}{|l|l|l|l|}
\hline No. & Pertanyaan & Jawaban & Persentase \\
\hline 1. & Cita Rasa Minuman & 17 & $18,47 \%$ \\
\hline 2. & Cita Rasa Makanan & 9 & $9,78 \%$ \\
\hline 3. & Fasilitas yang Disediakan & 9 & $9,78 \%$ \\
\hline 4. & $\begin{array}{l}\text { Kecepatan dalam } \\
\text { Memproses Makanan dan } \\
\text { Minuman }\end{array}$ & 10 & $10,86 \%$ \\
\hline 5. & $\begin{array}{l}\text { Lokasi yang Dekat dengan } \\
\text { Kampus }\end{array}$ & 16 & $17,39 \%$ \\
\hline 6. & Sikap Karyawan & 15 & $16,30 \%$ \\
\hline 7. & Kemudahan Transaksi & 9 & $9,78 \%$ \\
\hline 8. & Pamor Brand & 3 & $3,26 \%$ \\
\hline 9. & Keragaman Menu & 3 & $3,26 \%$ \\
\hline 10. & Promo yang Menarik & 1 & $1,08 \%$ \\
\hline
\end{tabular}

Pra-survey dilakukan kepada 20 orang. Responden yang pernah melakukan pembelian di Ohayou dan berusia diatas 18 tahun. Hasil prasurvey yang dilakukan pada konsumen Ohayou menunjukkan 3 faktor utama yang membuat konsumen melakukan pembelian, yaitu cita rasa minuman, lokasi yang dekat dengan kampus, dan sikap karyawan. Cita rasa minuman merupakan atribut produk yang menentukan pembelian konsumen Ohayou. Lokasinya yang berada di seberang kampus UNPAR merupakan pelayanan yang diberikan untuk memudahkan akses konsumen untuk melakukan pembelian. Sikap karyawan juga termasuk dalam kualitas pelayanan yang diberikan Ohayou dengan mengutamakan pelayanan yang ramah dan cepat tanggap.

Mengacu pada pra-survey dan hasil wawancara dengan pemilik Ohayou dapat disimpulkan bahwa konsumen memperhatikan atribut produk dan pelayanan sebagai faktor penting dalam proses keputusan pembelian. Oleh sebab itu, penelitian ini bermaksud untuk mengetahui bagaimana penilaian konsumen Ohayou terhadap atribut produk dan kualitas pelayanan Ohayou serta mengetahui bagaimana pengaruh atribut produk dan kualitas pelayanan terhadap proses keputusan pembelian konsumen Ohayou Bandung. 


\section{KAJIAN TEORI}

\section{Produk}

Produk adalah berbagai hal yang dapat ditawarkan ke pasar untuk memuaskan kebutuhaan ataupun keinginan, hal ini termasuk barang fisik, pelayanan, pengalaman, acara (event) orang, tempat, perlengkapan, organisasi, informasi dan ide (Kotler \& Keller, 2016).

\section{Atribut Produk}

Atribut produk adalah serangkaian manfaat dari suatu produk yang dikomunikasikan lalu disalurkan kepada pelanggan (Philip Kotler et al., 2018). Terdapat beberapa atribut dalam produk, yaitu :

\section{Kualitas}

Kualitas ditentukan oleh kemampuan produk dalam memenuhi kebutuhan dan kepuasan pelanggan yang berdampak pada nilai pelanggan (customer value) (Kotler, Armstrong, \& Opresnik, 2018). Hal ini dapat dilihat dari segi durabilitas, reliabilitas, ketepatan, kemudahan pengoperasian, dan reparasi produk (Sumaryati \& Gregie, 2016).

2. Gaya dan Desain

Gaya merujuk pada tampilan sebuah produk sedangkan desain mengarah pada kegunaan produk yang sesuai dengan gaya-nya. Desain yang baik dapat tercipta bila perusahaan melakukan observasi terhadap pelanggan dan mengerti kebutuhannya. Fokus utama pada desain adalah bagaimana pelanggan akan memperoleh manfaat dan bagaimana pelanggan menggunakan produk tersebut (Kotler, Armstrong, \& Opresnik, 2018).

3. Fitur

Fitur merupakan komponen pelengkap dari komponen dasarnya (Kotler \& Keller, 2016) Fitur menunjukkan keistimewaan sebuah produk yang membedakannya dengan produk sejenis (Sumaryati \& Gregie, 2016). Dengan adanya komposisi fitur yang berbeda-beda akan tercipta model produk yang berbeda pula. Agar dapat bersaing secara efektif, perusahaan perlu menawarkan sebuah fitur baru yang bernilai dimata pelanggan (Kotler, Armstrong, \& Opresnik, 2018).

4. Nama brand

Brand umunya digunakan untuk mengindentifikasi suatu produk dan jasa dari suatu produsen atau penjual (seller) yang umumnya dapat berupa nama, istilah, tanda, simbol, dan desain maupun gabungan ataupun kombinasi dari keempatnya (Philip Kotler et al., 2018; Sumaryati \& Gregie, 2016).

\section{Kemasan}

Secara umum, kemasan berfungsi untuk membungkus ataupun mewadahi suatu produk Proses pengemasan terkait dengan proses dalam merancang dan membuat wadah (container) atau pembungkus (wrapper) suatu produk (Philip Kotler et al., 2018). Saat ini, kemasan merupakan salah satu alat promosi yang dapat membantu perusahaan menarik pelanggannya dengan mengkomunikasikan brand positioning (agar kemasan maupun brand lebih mudah diingat oleh konsumen) (Philip Kotler et al., 2018).

6. Labelling and Logo

Label menunjukkan identifikasi, penilaian, deskripsi dan/atau promosi produk sebagai sarana informasi dan/atau promosi kepada konsumen (Kotler \& Keller, 2016). Adapun label bertujuan untuk mengidentifikasi pembuat produk, kapan produk dibuat, dimana produk dibuat, komposisi produk, bagaimana penggunaan produk, dan lain sebagainya. Menurut Kotler \& Pfoerstch dalam Aji dan Semuel (2015), logo adalah tampilan grafis dari nama brand atau perusahaan. Kekuatan simbol tidak boleh dianggap remeh "karena manusia cenderung menjadi lebih mudah menerima citra dan symbol dibanding yang lainnya,logo yang kuat dapat memberi kohesi dan membangun kesadaran identitas merek, memudahkan pengenalan dan ingatan kembali". Label dan logo membantu perusahaan untuk meningkatkan hubungan dengan pelanggan ketika pelanggan terinternalisasi melihat label atau logo sebagai simbol dari brand suatu perusahaan (Philip Kotler et al., 2018).

\section{Product Support Service}

Perusahaan umumnya menawarkan layanan dukungan yang bertujuan untuk meningkatkan produk aktual. Layanan dukungan adalah bagian penting dari pengalaman merek pelanggan secara keseluruhan. Hal ini agar perusahaan dapat menjaga pelanggan tetap senang setelah penjualan sehingga perusahaan mampu membangun hubungan yang langgeng dengan pelanggan (Philip Kotler et al., 2018). 


\section{Kualitas Pelayanan}

"Jasa atau pelayanan adalah tindakan yang ditawarkan satu pihak kepada pihak lain yang tidak berwujud dan tidak mengakibatkan kepemilikan sesuatu" (Soenawan, Malonda, \& Aprilia, 2015). Penyampaian pelayanan yang unggul membutuhkan pengelolaan harapan pelanggan. Harapan pelanggan memainkan peran penting dalam menilai pengalaman dan evaluasi pelayanan. Perusahaan harus mengelola kualitas pelayanan dengan memahami dampak dari setiap pelayanan yang ditawarkan ataupun diberikan (Philip Kotler \& Keller, 2016).

Menurut Kotler dan Keller (2016) terdapat 5 dimensi dalam kualitas pelayanan, yaitu dijelaskan sebagai berikut:

1. Kehandalan (Reliability)

Kemampuan perusahaan untuk menyediakan pelayanan kinerja yang akurat dan handal. Hal ini dapat diwujudkan bila karyawan memiliki pengetahuan yang memadai untuk menjawab pertanyaan pelanggan sehingga pelanggan dapat menemukan solusi atas masalahnya.

2. Daya Tanggap (Responsiveness)

Kemampuan perusahaan untuk membantu konsumen dengan menyediakan layanan yang cepat. Adapun contoh dari daya tanggap ini adalah ketika karyawan dengan cepat memenuhi kebutuhan konsumen seperti segera memberikan tisu ketika kopi yang dipesan konsumen berupa kopi dingin yang akan mengeluarkan embun sehingga permukaan gelas kopi dingin akan basah.

3. Jaminan (Assurance)

Karyawan yang berpengetahuan dan sopan serta memiliki kemampuan untuk meningkatkan rasa percaya dan rasa aman bagi pelanggan

4. Empati (Empathy)

Perusahaan memiliki pemahaman dan perhatian terhadap setiap pelanggan secara individual. Karyawan paham terhadap kebutuhan setiap pelanggan sehingga membentuk ikatan emosional dan bertindak secara personal. Contohnya adalah ketika karyawan dapat segera merespon selera pelanggan yang cenderung lebih suka manis (dengan gula banyak), lebih suka dinging (dengan es yang banyak) dan lain sebagainya.

5. Bukti Fisik (Tangibles)

Bukti fisik meliputi tampilan fasilitas fisik yang menarik dan menunjang, peralatan dan perlengkapan yang lengkap untuk memberikan pelayanan.

\section{Keputusan Pembelian}

Menurut Kotler \& Keller (2016), keputusan pembelian berkaitan dengan pertanyaan mengenai alasan pelanggan membeli barang seperti apa yang dibeli, di mana barang akan dibeli, berapa dan bagaimana mereka membeli barang, terakhir mengapa mereka membeli barang tersebut.

Keputusan pembelian dipengaruhi oleh kombinasi kompleks antara faktor eksternal dan internal. Keputusan pembelian tercemin dan berkontribusi pada gaya hidup dan keseluruhan pola perilaku dan interaksi manusia.

Menurut Kotler dan Keller (2016) terdapat 5 tahapan dalam proses keputusan pembelian yang dijelaskan sebagai berikut:

1. Pengenalan Masalah (Problem Recognition)

Proses pembelian dimulai ketika pembeli sadar akan kebutuhan atau munculnya masalah. Masalah dapat muncul dari dalam diri maupun dari lingkungan eksternal. Pelaku bisnis perlu mengumpulkan informasi tentang penyebab adanya kebutuhan tersebut dan menyusun strategi untuk menarik minat pasar.

2. Pencarian Informasi (Information Search)

Ketika pembeli merasa perlu untuk memenuhi kebutuhan atau menyelesaikan masalah, pembeli akan mencari informasi tentang produk tersebut. Pencarian informasi yang bersifat aktif contohnya adalah menelaah komposisi, menanyakan pendapat relasi, dan datang ke toko untuk mempelajari produk.

3. Evaluasi Alternatif (Evaluation of Alternatives) Dengan tingkat kompetitif suatu merek dengan yang lain, pembeli membandingkan satu produk dengan produk substitusi lain. Pembeli akan mencari perbandingan dari segala aspek, misalnya spesifikasi produk, kelebihan dan kekurangan, lokasi, brand image, dan sebagainya. Persepsi pembeli seperti kepercayaan, ikatan emosional, dan ekspektasi terhadap produk juga menentukan evaluasi produk.

4. Keputusan Pembelian (Purchase Decision)

Setelah tahap evaluasi, pembeli akan menilai produk mana yang paling sesuai untuk memenuhi kebutuhannya atau membantunya menyelesaikan masalah yang dihadapi. Setelah itu, pembeli akan memutuskan untuk 
melakukan pembelian berdasarkan preferensi terhadap brand pilihannya.

5. Perilaku Pasca Pembelian (Post-purchase Behavior)

Konsumen dapat mengalami kesenjangan antara ekspektasi dan realita suatu performa produk setelah melakukan pembelian. Jika performa produk melebihi ekspektasi konsumen, akan terbentuk kepuasan (satisfaction) terhadap produk tersebut dan berkemungkinan besar untuk melakukan pembelian ulang. Para pelaku bisnis perlu melakukan evaluasi untuk mempertahankan kepuasan konsumen.

\section{METODOLOGI}

\section{Jenis Penelitian}

Penelitian ini berjenis eksplanatori di mana penelitian ini bertujuan untuk menganalisis hubungan kausal antara atribut produk, kualitas pelayanan dan keputusan pembelian di Ohayou. Penelitian ini menguji teori atau hipotesis agar dapat menolak atau memperkuat teori atau hipotesis yang dimaksud (Sugiyono, 2016).

\section{Model Penelitian}

Berikut adalah model penelitian yang menunjukkan pengaruh variabel $\mathrm{X} 1$ dan $\mathrm{X} 2$ dengan variabel Y.

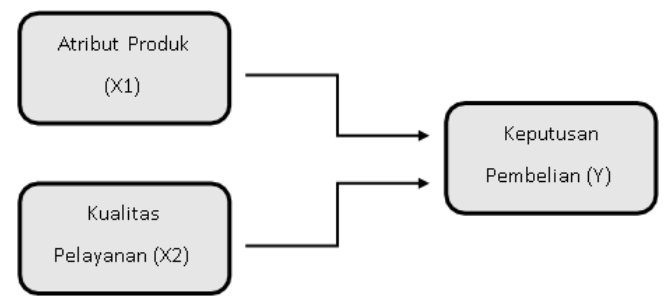

Gambar 1. Model Penelitian

Menurut Sugiyono (2019), variabel adalah atribut yang memiliki variasi tertentu yang digunakan penulis untuk mempelajari bidang atau kegiatan tertentu. Penelitian ini terdiri dari 3 variabel yaitu Atribut Produk (X1), Kualitas Pelayanan (X2), dan Keputusan Pembelian (Y). Variabel $\mathrm{X} 1$ dan $\mathrm{X} 2$ berperan sebagai variabel bebas (independen). Variabel $\mathrm{Y}$ berperan sebagai variabel terikat (dependen).

\section{Teknik Pengumpulan Data}

Penelitian ini menggunakan 3 metode pengumpulan data yaitu :
1. Wawancara

Wawancara dilakukan dengan melakukan tanya jawab dan diskusi dengan narasumber untuk mendapatkan informasi (Sugiyono, 2019). Adapun wawancara dilakukan dengan owner dan konsumen dari Ohayou untuk mendapatkan informasi lebih lanjut.

2. Kuesioner

Kuesioner disebarkan kepada konsumen Ohayou dengan memberikan pertanyaan tertulis seputar atribut produk, kualitas pelayanan, dan keputusan pembelian yang dilakukan konsumen (Sugiyono, 2019). Penyebaran sample dilakukan dengan Teknik purposive sampling di mana kuisioner yang disebarkan hanya kepada konsumen Ohayo dengan kriteria sebagai berikut:

1. Pernah melakukan pembelian di Ohayou

2. Pernah melakukan transaksi langsung di Ohayou

3. Pernah menggunakan fasilitas yang disediakan Ohayou

4. Berusia diatas 18 tahun

Untuk menentukan sampel minimal yang dapat mewakili populasi pada penelitian ini, dihitung dengan rumus berikut:

$$
\mathrm{n}=\frac{0,25 \times z^{2}}{e^{2}}
$$

Keterangan:

$\mathrm{n}=$ Jumlah sampel

$\mathrm{z}=$ Tingkat kepercayaan $\mathrm{e}=$ Sampling error

Diasumsikan tingkat kepercayaan 95\% dan sampling error yang digunakan sebesar 10\% sehingga z sebesar 1,96. Maka, besarnya sampel minimun adalah:

$\mathrm{n}=(0,25 \times \llbracket 1,96 \rrbracket \wedge 2) / \llbracket 0,1 \rrbracket \wedge 2=96,04$ responden

Berdasarkan perhitungan di atas, sampel minimun yang dibutuhkan sebanyak 96,04 responden, dibulatkan menjadi 97 responden. Dalam mengantisipasi ketidaksesuaian dalam proses pengisian kuesioner, penulis menetapkan sampel sebesar 100 responden.

\section{Observasi}

Kegiatan mengamati aktivitas yang berhubungan dengan perilaku manusia, proses kerja, dan objek lain yang perlu diamati untuk mendapatkan fakta (Sugiyono, 2019). Observasi yang dilakukan berupa observasi partisipan dimana penulis terlibat dalam kegiatan operasional Ohayou sehari-hari. 


\section{Operasionalisasi Variabel}

Tabel 2. Operasionalisasi Variabel

\begin{tabular}{|c|c|c|}
\hline Variabel & Dimensi & Indikator \\
\hline \multirow{16}{*}{$\begin{array}{l}\text { Atribut } \\
\text { Produk } \\
\text { (AP) }\end{array}$} & \multirow{5}{*}{ Kualitas } & Ohayou menyajikan cita rasa produk yang enak \\
\hline & & Ohayou konsisten dalam mempertahankan cita rasa yang disajikan \\
\hline & & Kualitas yang serupa dengan produk Ohayou sulit ditemui di tempat lain \\
\hline & & Ohayou menyajikan produk dalam porsi yang cukup \\
\hline & & Ohayou menyajikan produk secara menarik \\
\hline & \multirow{3}{*}{ Fitur } & Ohayou memiliki varian menu yang beragam \\
\hline & & Ohayou menyediakan produk yang sesuai dengan keinginan konsumen \\
\hline & & Ohayou menyediakan fasilitas yang memadai \\
\hline & \multirow{2}{*}{ Desain } & Ohayou memiliki display produk yang menarik \\
\hline & & Ohayou memiliki desain interior yang menarik \\
\hline & \multirow{3}{*}{ Merek } & Brand Ohayou memiliki reputasi baik \\
\hline & & Brand Ohayou mudah diingat \\
\hline & & Ohayou memberikan nilai prestis ketika konsumen membeli produk atau datang ke tempat \\
\hline & \multirow{3}{*}{ Kemasan } & Kemasan produk Ohayou tidak mudah rusak \\
\hline & & Kemasan produk Ohayou memiliki tampilan menarik \\
\hline & & Kemasan produk Ohayou membantu konsumen dalam mengonsumsi produk tersebut \\
\hline \multirow{16}{*}{$\begin{array}{l}\text { Kualitas } \\
\text { Pelayanan } \\
\quad(\mathrm{KP})\end{array}$} & \multirow{3}{*}{$\begin{array}{l}\text { Kehandalan } \\
\text { (Reliability) }\end{array}$} & Kemampuan karyawan Ohayou memadai dalam membuat minuman dan makanan \\
\hline & & Karyawan Ohayou mampu menjelaskan menu dengan baik \\
\hline & & Menu yang diantar sesuai dengan yang dipesan oleh konsumen \\
\hline & \multirow{2}{*}{$\begin{array}{c}\text { Daya Tanggap } \\
\text { (Responsiveness) }\end{array}$} & Karyawan Ohayou cepat tanggap saat melayani konsumen \\
\hline & & Karyawan Ohayou menyelesaikan keluhan dengan sigap \\
\hline & \multirow{4}{*}{$\begin{array}{c}\text { Jaminan } \\
\text { (Assurance) }\end{array}$} & Ohayou berupaya menjaga kenyamanan konsumen yang berkunjung \\
\hline & & Transaksi dilakukan dengan tepat sesuai dengan perhitungan tagihan \\
\hline & & Transaksi dilakukan denganaman \\
\hline & & Konsumen merasa yakin akan kehalalan produk yang dijual Ohayou \\
\hline & \multirow{3}{*}{$\begin{array}{c}\text { Empati } \\
\text { (Empathy) }\end{array}$} & Karyawan Ohayou melayani dengan sopan dan ramah \\
\hline & & Karyawan Ohayou menanggapi kritik dan saran yang diberikan dengan baik \\
\hline & & Karyawan Ohayou memahami kebutuhan konsumen dengan baik \\
\hline & \multirow{4}{*}{$\begin{array}{l}\text { Bukti Fisik } \\
\text { (Tangibles) }\end{array}$} & Karyawan Ohayou berpakaian rapi dan sopan \\
\hline & & Ruangan Ohayou selalu dalam keadaan bersih dan nyaman \\
\hline & & Fasilitas yang disediakan Ohayou selalu dalam keadaan bersih dan baik \\
\hline & & Ohayou menggunakan mesin yang modern untuk membuat kopi \\
\hline \multirow{7}{*}{$\begin{array}{c}\text { Proses } \\
\text { Keputusan } \\
\text { Pembelian } \\
\text { (PKP) }\end{array}$} & \multirow{3}{*}{$\begin{array}{l}\text { Pengenalan } \\
\text { Masalah }\end{array}$} & Saya mengunjungi Ohayou ketika menginginkan kopi \\
\hline & & Saya mengunjungi Ohayou untuk mengisi waktu luang dan bersosialisasi \\
\hline & & $\begin{array}{c}\text { Saya mengunjungi Ohayou ketika membutuhkan fasilitas yang disediakan untuk menunjang } \\
\text { aktivitas saya (mengerjakan tugas, meeting, dll) }\end{array}$ \\
\hline & \multirow{2}{*}{$\begin{array}{l}\text { Pencarian } \\
\text { Informasi }\end{array}$} & Saya memperoleh informasi mengenai Ohayou dari teman atau relasi \\
\hline & & Saya memperoleh informasi mengenai Ohayou dari social media \\
\hline & \multirow{2}{*}{$\begin{array}{l}\text { Evaluasi } \\
\text { Alternatif }\end{array}$} & Produk yang dijual Ohayoulebih baik dibanding coffee shop sekelasnya di daerah Ciumbuleuit \\
\hline & & $\begin{array}{c}\text { Pelayanan dan fasilitas di Ohayou lebih baik dibanding coffee shop sekelasnya di daerah } \\
\text { Ciumbuleuit }\end{array}$ \\
\hline
\end{tabular}




\begin{tabular}{|c|c|c|}
\hline & Membeli di Ohayou lebih menguntungkan dibanding coffee shop lain di daerah Ciumbuleuit \\
\cline { 2 - 3 } $\begin{array}{c}\text { Keputusan } \\
\text { Pembelian }\end{array}$ & $\begin{array}{c}\text { Saya memutuskan untuk membeli produk Ohayou atas preferensi saya terhadap produk dan } \\
\text { pelayanannya }\end{array}$ \\
\cline { 2 - 3 } & $\begin{array}{c}\text { Perilaku Pasca } \\
\text { Pembelian }\end{array}$ & Saya merasa keputusan saya untuk membeli di Ohayou adalah keputusan yang tepat \\
\cline { 2 - 3 } & Saya akan membagikan informasi positif mengenai pengalaman saya mengunjungi Ohayou \\
\hline
\end{tabular}

\section{Teknik Analisis Data}

Teknik analisis data merupakan proses dalam penelitian untuk mengolah data yang didapatkan dari responden (Sugiyono, 2019). Analisis data bertujuan untuk mendapatkan jawaban atas rumusan masalah yang telah dirumuskan penulis. Dalam penelitian kuantitatif, analisis data menggunakan statistic, uji statistic dilakukan dengan menggunakan SPSS. Adapun Teknik analisis data yang dilakukan dalam penelitian ini antara lain :

\section{Uji Validitas}

Suatu penelitian dapat dinyatakan valid apabila terdapat kesamaan antara data yang terkumpul dengan objek yang diteliti (Sugiyono, 2019). Instrumen yang digunakan dalam penelitian harus bersifat valid yang berarti sesuai dengan objek yang harusnya diukur. Penelitian ini menggunakan validitas konstruksi dengan menggunakan rumus Pearson Product Moment dengan menggunakan program SPSS. Untuk menentukan validitas, penulis akan menyebarkan kuesioner kepada 40 responden terlebih dahulu. Menurut r-tabel dari Pearson Product Moment:

1. Koefisien validitas lebih besar dari 0,312 dinyatakan valid

2. Koefisien validitas lebih kecil dari 0,312 dinyatakan tidak valid

\section{Uji Reliabilitas}

Hasil penelitian dapat dinyatakan reliabel bila terdapat kesamaan data dalam waktu yang berbeda (Sugiyono, 2019). Instrumen yang reliabel adalah instrumen yang jika digunakan berkali-kali untuk mengukur objek yang sama dapat menghasilkan data yang sama. Penelitian ini menggunakan pengujian reliabilitas instrumen secara internal menggunakan rumus Cronbach Alpha dengan menggunakan program SPSS. Hasil dari uji reliabilitas dapat dikatakan reliabel jika memiliki angka diatas 0,6 .

\section{Uji Normalitas}

Uji normalitas dilakukan untuk menunjukkan sebaran data yang diambil sesuai dengan populasi sehingga menghasilkan distribusi normal atau mendekati normal (Ghozali, 2016). Penelitian ini menggunakan metode One- Sample Kolmogorov-Smirnov dengan ketentuan seperti berikut :

Tabel 3. Ketentuan Metode One-Sample Kolmogorov-

\begin{tabular}{|c|c|}
\multicolumn{2}{|c}{ Smirnov } \\
\hline Signifikansi & Distribusi \\
\hline$\leq 0,05$ & Tidak normal \\
\hline$>0,05$ & Normal \\
\hline
\end{tabular}

\section{Uji Heteroskedastisitas}

Uji heteroskedastisitas adalah uji asumsi klasik dalam model regresi yang bertujuan untuk mengetahui adanya ketidaksamaan varian dalam nilai residual pada suatu periode pengamatan ke periode pengamatan lainnya (Priyatno, 2018). Penelitian ini menggunakan uji heteroskedastisitas dengan melihat pola titik-titik pada scatterplot regresi dengan bantuan program SPSS. Hasil yang baik tidak menunjukkan adanya heteroskedastisitas apabila:

1. Pada grafik scatterplot, titik data penyebar di atas dan di bawah atau di sekitar angka 0 pada sumbu Y

2. Grafik scatterplot tidak membentuk suatu pola tertentu yang teratur

\section{Uji Korelasi Parsial}

Menurut Priyatno (2018), analisis korelasi sederhana berguna untuk mengetahui kekuatan hubungan, arah hubungan, dan signifikansi hubungan antara dua variabel. Nilai koefisien korelasi berkisar antara 0 hingga 1 atau 0 hingga 1. Semakin mendekati 1 atau -1 , hubungan antar variabel semakin erat. Sebaliknya, jika mendekati 0 , maka hubungan semakin lemah. Uji korelasi pada penelitian ini berguna untuk mengetahui hubungan antara atribut produk (X1) dengan keputusan pembelian (Y) dan hubungan kualitas 
pelayanan (X2) dengan keputusan pembelian (Y). Penulis menggunakan program SPSS dengan perhitungan korelasi Pearson. Berikut adalah tabel interpretasi korelasi untuk nilai r:

Tabel 4. Interpretasi Korelasi

\begin{tabular}{|c|c|}
\hline Interval Koefisien & Tingkat Hubungan \\
\hline $0,000-0,199$ & Sangat Rendah \\
\hline $0,200-0,399$ & Rendah \\
\hline $0,400-0,599$ & Sedang \\
\hline $0,600-0,799$ & Kuat \\
\hline $0,800-1,000$ & Sangat Kuat \\
\hline
\end{tabular}

\section{Uji Multikolinearitas}

Uji multikolinearitas digunakan untuk mengetahui adanya korelasi sempurna atau mendekati sempurna antar variabel independen (Priyatno, 2018). Model regresi yang baik adalah tidak terjadinya korelasi sempurna atau mendekati sempurna. Multikolinearitas diuji dengan melihat nilai Tolerance dan Variance Inflation Factor (VIF). Analisis dilakukan dengan bantuan program SPSS. Model regresi tidak mengandung multikolinearitas apabila:

1. Nilai Tolerance lebih besar dari 0,1

2. Nilai VIF kurang dari 10

\section{Uji Regresi Linier Berganda}

Uji regresi linear berganda berguna untuk memprediksi seberapa tinggi nilai variable dependen bila nilai variable independent dimanipulasi (Sugiyono, 2016). Terdapat beberapa asumsi klasik dalam analisis regresi linier berganda, yaitu:

1. Residual memiliki distribusi normal

2. Tidak terdapat multikolinearitas

3. Tidak terdapat heteroskedastisitas

4. Tidak terdapat autokorelasi pada model

$$
y=a+\beta_{1} X_{1} \beta_{2} X_{2}+\mathrm{e}
$$

Keterangan:

$\mathrm{Y}=$ Variabel dependen (keputusan pembelian)

$\mathrm{a}=$ Konstanta

$\beta=$ Koefisien regresi

$\mathrm{X}=$ Variabel independen (atribut produk dan

kualitas pelayanan)

$\mathrm{e}=$ Error (diasumsikan nilai 0)

\section{Uji Hipotesa Parsial (Uji T)}

Uji $\mathrm{T}$ atau uji hipotesis parsial digunakan untuk mengukur pengaruh signifikan variabel independen terhadap variabel dependen secara parsial (Priyatno, 2018). Di dalam uji T, setiap variabel independen akan diuji secara terpisah untuk melihat pengaruhnya terhadap variabel dependen. Berikut adalah hipotesis untuk menguji koefisien variabel atribut produk (X1):

$H 0$ : Atribut produk tidak berpengaruh secara parsial terhadap keputusan pembelian konsumen Ohayou Bandung

$H 1$ : Atribut produk berpengaruh secara parsial terhadap keputusan pembelian konsumen Ohayou Bandung

Berikut adalah hipotesis untuk menguji

koefisien variabel kualitas pelayanan (X2):

$H 0$ : Kualitas pelayanan tidak berpengaruh secara parsial terhadap keputusan pembelian konsumen Ohayou Bandung

$H 1$ : Kualitas pelayanan berpengaruh secara parsial terhadap keputusan pembelian konsumen Ohayou Bandung

Tabel 5. Kriteria pengujian

\begin{tabular}{|l|l|}
\hline$t$ hitung $>\mathrm{t}$ tabel & $H 0$ ditolak \\
\hline $\mathrm{t}$ hitung $<\mathrm{t}$ tabel & $H 0$ diterima \\
\hline
\end{tabular}

Adapun signifikasi ditunjukan seperti table 8 , jika signifikansi $\leq 0,05$, maka $H 0$ ditolak. Jika signifikansi $\geq 0,05$, maka $H 0$ diterima.

\section{Uji Hipotesa Simultan (Uji F)}

Uji $F$ digunakan untuk mengukur seberapa signifikan besar pengaruh variabel independen terhadap variabel dependen (Priyatno, 2018). Hipotesis sebagai berikut:

$H 0$ : Atribut produk dan kualitas pelayanan tidak berpengaruh signifikan terhadap keputusan pembelian konsumen Ohayou Bandung

$H 1$ : Atribut produk dan kualitas pelayanan berpengaruh signifikan terhadap keputusan pembelian konsumen Ohayou Bandung

Kriteria pengambilan keputusan adalah jika signifikansi $\leq 0,05$, maka $H 0$ ditolak. Jika signifikansi $\geq 0,05$, maka $H 0$ diterima.

\section{Uji Koefisien Determinasi}

Uji koefisien determinasi atau $\mathrm{R}$ square dapat dilakukan bila hasil uji $\mathrm{F}$ memiliki nilai signifikan dimana terdapat pengaruh antara variable XI dan X2 ke Y. Koefisien dieterminasi menunjukkan seberapa besar pengaruh variable X1 
\& X2 (variable independent) terhadap variable $\mathrm{Y}$ (variable dependent) (Priyatno, 2018). Nilai koefisien determinasi dihitung dengan rumus:

$$
K D=r^{2} \times 100 \%
$$

Keterangan:

$\mathrm{KD}=$ Koefisien Determinasi

$r 2=$ Hasil Korelasi

Nilai koefisien atau $\mathrm{r}$ berkisar antara 0 hingga 1. Semakin mendekati angka 1, maka pengaruh variabel independen terhadap variabel dependen semakin erat.

\section{PEMBAHASAN DAN HASIL PENELITIAN}

\section{Uji Validitas}

Tabel 6. Hasil Pengujian Validitas

\begin{tabular}{|l|l|l|l|l|l|}
\hline Item & $\begin{array}{l}\text { r- } \\
\text { hitung }\end{array}$ & r-tabel & $\begin{array}{l}\text { Hitung } \\
\text { sig }\end{array}$ & sig & $\begin{array}{l}\text { Ketera } \\
\text { ngan }\end{array}$ \\
\hline AP 1 & 0,652 & 0,312 & 0,000 & 0,05 & VALID \\
\hline AP 2 & 0,399 & 0,312 & 0,011 & 0,05 & VALID \\
\hline AP 3 & 0,510 & 0,312 & 0,001 & 0,05 & VALID \\
\hline AP 4 & 0,645 & 0,312 & 0,000 & 0,05 & VALID \\
\hline AP 5 & 0,731 & 0,312 & 0,000 & 0,05 & VALID \\
\hline AP 6 & 0,595 & 0,312 & 0,000 & 0,05 & VALID \\
\hline AP 7 & 0,639 & 0,312 & 0,000 & 0,05 & VALID \\
\hline AP 8 & 0,403 & 0,312 & 0,010 & 0,05 & VALID \\
\hline AP 9 & 0,546 & 0,312 & 0,000 & 0,05 & VALID \\
\hline AP 10 & 0,573 & 0,312 & 0,000 & 0,05 & VALID \\
\hline AP11 & 0,613 & 0,312 & 0,000 & 0,05 & VALID \\
\hline AP 12 & 0,508 & 0,312 & 0,001 & 0,05 & VALID \\
\hline AP 13 & 0,613 & 0,312 & 0,000 & 0,05 & VALID \\
\hline AP 14 & 0,572 & 0,312 & 0,000 & 0,05 & VALID \\
\hline AP 15 & 0,555 & 0,312 & 0,000 & 0,05 & VALID \\
\hline AP 16 & 0,659 & 0,312 & 0,000 & 0,05 & VALID \\
\hline KP 1 & 0,756 & 0,312 & 0,000 & 0,05 & VALID \\
\hline KP 2 & 0,612 & 0,312 & 0,000 & 0,05 & VALID \\
\hline KP 3 & 0,603 & 0,312 & 0,000 & 0,05 & VALID \\
\hline KP 4 & 0,736 & 0,312 & 0,000 & 0,05 & VALID \\
\hline KP 5 & 0,564 & 0,312 & 0,000 & 0,05 & VALID \\
\hline KP 6 & 0,589 & 0,312 & 0,000 & 0,05 & VALID \\
\hline KP 7 & 0,542 & 0,312 & 0,000 & 0,05 & VALID \\
\hline KP 8 & 0,542 & 0,312 & 0,000 & 0,05 & VALID \\
\hline KP 9 & 0,697 & 0,312 & 0,000 & 0,05 & VALID \\
\hline KP 10 & 0,767 & 0,312 & 0,000 & 0,05 & VALID \\
\hline KP 1 1 & 0,725 & 0,312 & 0,000 & 0,05 & VALID \\
\hline KP 12 & 0,705 & 0,312 & 0,000 & 0,05 & VALID \\
\hline KP 13 & 0,506 & 0,312 & 0,001 & 0,05 & VALID \\
\hline KP 14 & 0,664 & 0,312 & 0,000 & 0,05 & VALID \\
\hline KP 15 & 0,646 & 0,312 & 0,000 & 0,05 & VALID \\
\hline KP 16 & 0,599 & 0,312 & 0,000 & 0,05 & VALID \\
\hline PKP 1 & 0,566 & 0,312 & 0,000 & 0,05 & VALID \\
\hline PKP 2 & 0,517 & 0,312 & 0,001 & 0,05 & VALID \\
\hline PKP 3 & 0,457 & 0,312 & 0,003 & 0,05 & VALID \\
\hline PKP 4 & 0,430 & 0,312 & 0,006 & 0,05 & VALID \\
\hline PKP 5 & 0,410 & 0,312 & 0,009 & 0,05 & VALID \\
\hline & & & & & \\
\hline
\end{tabular}

\begin{tabular}{|l|l|l|l|l|l|}
\hline PKP 6 & 0,735 & 0,312 & 0,000 & 0,05 & VALID \\
\hline PKP 7 & 0,544 & 0,312 & 0,000 & 0,05 & VALID \\
\hline PKP 8 & 0,707 & 0,312 & 0,000 & 0,05 & VALID \\
\hline PKP 9 & 0,759 & 0,312 & 0,000 & 0,05 & VALID \\
\hline PKP 10 & 0,715 & 0,312 & 0,000 & 0,05 & VALID \\
\hline PKP 11 & 0,653 & 0,312 & 0,000 & 0,05 & VALID \\
\hline PKP 12 & 0,703 & 0,312 & 0,000 & 0,05 & VALID \\
\hline
\end{tabular}

Penyebaran kuisioner dilakukan untuk menguji validitas dan reabilitas 44 item (pertanyaan) dalam kuisioner. Kusioner disebarkan kepada 40 responden yang merupakan konsumen Ohayou. Tabel 6 menunjukkan bahwa seluruh item memiliki nilai r-hitung yang lebih besar dari $r$ tabel. Maka dari itu, 44 pernyataan yang digunakan sebagai indikator dalam penelitian ini dapat dinyatakan valid.

\section{Uji Reliabilitas}

Tabel 7. Hasil Pengujian Reliabilitas

\begin{tabular}{|l|l|l|l|}
\hline Variabel & $\begin{array}{l}\text { Cronbach } \\
\text { Alpha }\end{array}$ & $\begin{array}{l}\text { Nilai } \\
\text { Standar }\end{array}$ & Keterangan \\
\hline $\begin{array}{l}\text { Atribut } \\
\text { Produk }\end{array}$ & 0,865 & 0,6 & RELIABEL \\
\hline $\begin{array}{l}\text { Kualitas } \\
\text { Pelayanan }\end{array}$ & 0,902 & 0,6 & RELIABEL \\
\hline $\begin{array}{l}\text { Keputusan } \\
\text { Pembelian }\end{array}$ & 0,813 & 0,6 & RELIABEL \\
\hline
\end{tabular}

Nilai Cronbach alpa harus lebih besar dari 0,6 agar penelitian ini reliabel. Berdasarkan tabel 10 , variabel atribut produk, kualitas pelayanan, dan keputusan pembelian memiliki nilai cronbach alpha diatas 0,6 sehingga dapat dinyatakan bahwa ketiga variable tersebut reliabel dan layak digunakan untuk penelitian ini.

\section{Data Profil Responden}

Responden yang dipilih pada penelitian ini adalah mereka yang sudah pernah melakukan pembelian langsung dan menggunakan fasilitas di Ohayou. Tabel 8 menunjukkan rentang usia responden Ohayou.

Tabel 8. Usia Responden

\begin{tabular}{|l|l|l|l|}
\hline No. & Usia & Frekuensi & $\begin{array}{l}\text { Persentas } \\
\text { e }\end{array}$ \\
\hline 1. & $<18$ tahun & 0 & $0 \%$ \\
\hline 2. & $18-25$ tahun & 94 & $94 \%$ \\
\hline 3. & $25-30$ tahun & 5 & $5 \%$ \\
\hline 4. & $>30$ tahun & 1 & $1 \%$ \\
\hline \multicolumn{2}{|l|}{ Total } & 100 & $100 \%$ \\
\hline
\end{tabular}

Berdasarkan tabel 8, mayoritas responden pada penelitian ini memiliki rentang usia 18-25 tahun, yaitu sebanyak 94 responden. Selain itu, 5 
responden memiliki rentang usia 25-30 tahun dan 1 responden berusia diatas 30 tahun.

\section{Analisis Distribusi Frekuensi}

Rentang interval digunakan untuk membuat kategori, hal ini dimaksudkan agar nilai skor dari setiap variabel penelitian dapat dikategorikan ke kriteria atau kelompok tertentu. Penyusunan tabel distribusi frekuensi menggunakan rumus seperti berikut ini :

$$
=\frac{\text { Nilai persentase max.- Nilai persentase min }}{\text { Skala }}
$$

Hasil perhitungan berdasarkan rumus di atas diketahui bahwa rentang interval untuk setiap kategori adalah $16 \%$ sehingga diperoleh rentang interval untuk setiap kategori seperti berikut ini :

Tabel 9. Interval Distribusi Frekuensi

\begin{tabular}{|l|l|l|}
\hline Interval Korelasi & Kriteria & $\begin{array}{l}\text { Bob } \\
\text { ot } \\
\text { nilai }\end{array}$ \\
\hline $20,00 \%-35,99 \%$ & Sangat Tidak Baik & 1 \\
\hline $36,00 \%-51,99 \%$ & Tidak Baik & 2 \\
\hline $52,00 \%-67,99 \%$ & Kurang Baik & 3 \\
\hline $68,00 \%-83,99 \%$ & Baik & 4 \\
\hline $84,00 \%-100,00 \%$ & Sangat Baik & 5 \\
\hline
\end{tabular}

Perhitungan dengan tabel distribusi frekuensi menggunakan skor aktual dan skor ideal. Skor aktual dihitung berdasarkan tanggapan seluruh responden dikali bobot nilainya. Skor ideal sebesar 500 yang berasal dari bobot nilai tertinggi (5) dan responden yang berjumlah 100 responden. Skor ideal didapatkan dengan asumsi bahwa semua responden memilih jawaban tertinggi atau bobot nilai tertinggi.

\section{Distribusi Frekuensi Atribut Produk}

Variabel atribut produk terdiri dari 5 dimensi, yaitu kualitas, fitur, desain, merek, dan kemasan. Setiap dimensi memiliki indikator yang digunakan untuk mengetahui tanggapan responden atas dimensi tersebut yang pada akhirnya akan berpengaruh terhadap penilaian responden terhadap variabel atribut produk. Terdapat tanggapan dari 100 responden atas 16 pernyataan mengenai variabel atribut produk seperti dijabarkan dalam tabel-tabel berikut ini :
Tabel 10. Dimensi Kualitas

\begin{tabular}{|c|c|c|c|c|c|c|}
\hline $\begin{array}{l}\mathbf{N} \\
\mathbf{0} \\
\cdot\end{array}$ & Pernyataan & \multicolumn{2}{|c|}{ Kriteria } & $\begin{array}{l}\text { Sko } \\
\mathbf{r} \\
\text { Akt } \\
\text { ual }\end{array}$ & $\begin{array}{l}\text { Skor } \\
\text { Aktual } \\
: \\
\text { Skor } \\
\text { Ideal } \\
(\%)\end{array}$ & $\begin{array}{l}\text { Kateg } \\
\text { ori }\end{array}$ \\
\hline \multirow{5}{*}{1} & Ohayou & STS & 0 & \multirow{5}{*}{440} & \multirow{5}{*}{$88 \%$} & \multirow{5}{*}{$\begin{array}{l}\text { Sanga } \\
\text { t Baik }\end{array}$} \\
\hline & menyajikan & $\mathrm{TS}$ & 0 & & & \\
\hline & cita rasa & $\mathrm{KS}$ & 5 & & & \\
\hline & produk yang & $\mathrm{S}$ & 50 & & & \\
\hline & enak & $\mathrm{SS}$ & 45 & & & \\
\hline \multirow{5}{*}{2} & Ohayou & STS & 0 & \multirow{5}{*}{409} & \multirow{5}{*}{$81,8 \%$} & \multirow{5}{*}{ Baik } \\
\hline & konsisten & TS & 3 & & & \\
\hline & dalam & $\mathrm{KS}$ & 15 & & & \\
\hline & mempertaha & $\mathrm{S}$ & 52 & & & \\
\hline & $\begin{array}{l}\text { rasa yang } \\
\text { disajikan }\end{array}$ & SS & 30 & & & \\
\hline \multirow{5}{*}{3} & Kualitas & STS & 1 & \multirow{5}{*}{356} & \multirow{5}{*}{$71,2 \%$} & \multirow{5}{*}{ Baik } \\
\hline & yang serupa & $\mathrm{TS}$ & 14 & & & \\
\hline & dengan & KS & 29 & & & \\
\hline & produk & $\mathrm{S}$ & 40 & & & \\
\hline & $\begin{array}{l}\text { Ohayou } \\
\text { sulit ditemui } \\
\text { di tempat } \\
\text { lain }\end{array}$ & SS & 16 & & & \\
\hline \multirow{5}{*}{4} & Ohayou & STS & 0 & \multirow{5}{*}{386} & \multirow{5}{*}{$77,2 \%$} & \multirow{5}{*}{ Baik } \\
\hline & menyajikan & TS & 7 & & & \\
\hline & produk & $\mathrm{KS}$ & 21 & & & \\
\hline & dalam porsi & $\mathrm{S}$ & 51 & & & \\
\hline & yang cukup & SS & 21 & & & \\
\hline \multirow{5}{*}{5} & Ohayou & STS & 0 & \multirow{5}{*}{384} & \multirow{5}{*}{$76,8 \%$} & \multirow{5}{*}{ Baik } \\
\hline & menyajikan & $\mathrm{TS}$ & 4 & & & \\
\hline & produk & $\mathrm{KS}$ & 29 & & & \\
\hline & secara & $\mathrm{S}$ & 46 & & & \\
\hline & menarik & $\mathrm{SS}$ & 21 & & & \\
\hline \multicolumn{4}{|c|}{ Total } & 1975 & $79 \%$ & Baik \\
\hline
\end{tabular}

Dimensi kualitas seperti ditunjukkan pada tabel 10, dikategorikan baik dengan persentase sebesar 79\%. 95 responden menilai Ohayou menyajikan cita rasa produk yang enak dan konsisten dalam mempertahankan cita rasa yang disajikan. Hal ini dikarenakan Ohayou konsisten dalam pemilihan bahan baku biji kopi sehingga mampu menghasilkan cita rasa yang tetap sama. 56 responden merasa sulit menemukan kualitas yang serupa dengan produk Ohayou di tempat lain. Namun, terdapat 44 responden yang menganggap produk dengan kualitas serupa dengan Ohayou dapat ditemukan di tempat lain. Hal ini disebabkan karena banyaknya kedai kopi pesaing yang berada di Ciumbuleuit sehingga responden memiliki pilihan yang cukup luas atas preferensinya. Dalam penyajian produknya, 67 responden menganggap produk yang disajikan Ohayou memiliki porsi yang cukup dan disajikan secara menarik. 
Tabel 11. Dimensi Fitur

\begin{tabular}{|c|c|c|c|c|c|c|}
\hline $\begin{array}{l}\mathbf{N} \\
\mathbf{0}\end{array}$ & Pernyataan & \multicolumn{2}{|c|}{ Kriteria } & $\begin{array}{l}\text { Sko } \\
\text { r } \\
\text { Akt } \\
\text { ual }\end{array}$ & $\begin{array}{l}\text { Skor } \\
\text { Aktua } \\
1 \div \\
\text { Skor } \\
\text { Ideal } \\
(\%)\end{array}$ & $\begin{array}{l}\text { Kat } \\
\text { egor } \\
\text { i }\end{array}$ \\
\hline \multirow[t]{5}{*}{1.} & \multirow{5}{*}{$\begin{array}{l}\text { Ohayou } \\
\text { memiliki } \\
\text { varian menu } \\
\text { yang beragam }\end{array}$} & $\begin{array}{l}\text { STS } \\
\end{array}$ & 0 & \multirow[t]{5}{*}{342} & \multirow[t]{5}{*}{$68,4 \%$} & \multirow[t]{5}{*}{ Baik } \\
\hline & & TS & 16 & & & \\
\hline & & KS & 36 & & & \\
\hline & & $\mathrm{S}$ & 38 & & & \\
\hline & & SS & 10 & & & \\
\hline \multirow[t]{5}{*}{2.} & \multirow{5}{*}{$\begin{array}{l}\text { Ohayou } \\
\text { menyediakan } \\
\text { produk yang } \\
\text { sesuai dengan } \\
\text { selera } \\
\text { konsumen }\end{array}$} & STS & 0 & \multirow[t]{5}{*}{397} & \multirow[t]{5}{*}{$79,4 \%$} & \multirow[t]{5}{*}{ Baik } \\
\hline & & TS & 1 & & & \\
\hline & & $\mathrm{KS}$ & 20 & & & \\
\hline & & $S$ & 60 & & & \\
\hline & & SS & 19 & & & \\
\hline \multirow[t]{5}{*}{3.} & \multirow{5}{*}{$\begin{array}{l}\text { Ohayou } \\
\text { menyediakan } \\
\text { fasilitas yang } \\
\text { memadai }\end{array}$} & STS & 0 & \multirow[t]{5}{*}{395} & \multirow[t]{5}{*}{$79 \%$} & \multirow[t]{5}{*}{ Baik } \\
\hline & & $\mathrm{TS}$ & 3 & & & \\
\hline & & $\mathrm{KS}$ & 19 & & & \\
\hline & & $\mathrm{S}$ & 58 & & & \\
\hline & & SS & 20 & & & \\
\hline \multicolumn{4}{|c|}{ Total } & $\begin{array}{l}113 \\
4\end{array}$ & $75,6 \%$ & Baik \\
\hline
\end{tabular}

Hasil dari dimensi fitur seperti pada tabel 11 menunjukkan bahwa $75 \%$ responden menilai baik indikator dari dimensi fitur. Keragaman varian menu Ohayou dapat dikategorikan baik di mana Ohayou berfokus pada varian minuman berbasis kopi, namun 52 responden yang mencari minuman non-coffee memiliki sedikit pilihan di Ohayou sehingga kurang setuju bahkan tidak setuju atas pernyataan ini. Selain itu, sebanyak 79 responden menganggap Ohayou menyediakan produk yang sesuai dengan selera konsumen dan menyediakan fasilitas yang memadai.

Tabel 12. Dimensi Desain

\begin{tabular}{|c|c|c|c|c|c|c|}
\hline $\begin{array}{l}\mathbf{N} \\
\text { o. }\end{array}$ & Pernyataan & \multicolumn{2}{|c|}{ Kriteria } & $\begin{array}{l}\text { Skor } \\
\text { Aktua } \\
\text { l }\end{array}$ & $\begin{array}{l}\text { Skor } \\
\text { Aktua } \\
1 \div \\
\text { Skor } \\
\text { Ideal } \\
(\%)\end{array}$ & $\begin{array}{l}\text { Kate } \\
\text { gori }\end{array}$ \\
\hline \multirow[t]{5}{*}{1.} & \multirow{5}{*}{$\begin{array}{l}\text { Ohayou } \\
\text { memiliki } \\
\text { display } \\
\text { produk yang } \\
\text { menarik }\end{array}$} & STS & 0 & \multirow[t]{5}{*}{392} & \multirow[t]{5}{*}{$78,4 \%$} & \multirow[t]{5}{*}{ Baik } \\
\hline & & TS & 2 & & & \\
\hline & & $\mathrm{KS}$ & 27 & & & \\
\hline & & $\mathrm{S}$ & 48 & & & \\
\hline & & SS & 23 & & & \\
\hline \multirow[t]{5}{*}{2.} & \multirow{5}{*}{$\begin{array}{l}\text { Ohayou } \\
\text { memiliki } \\
\text { desain } \\
\text { interior } \\
\text { yang } \\
\text { menarik }\end{array}$} & STS & 0 & \multirow[t]{5}{*}{445} & \multirow[t]{5}{*}{$89 \%$} & \multirow{5}{*}{$\begin{array}{l}\text { Sang } \\
\text { at } \\
\text { Baik }\end{array}$} \\
\hline & & TS & 0 & & & \\
\hline & & $\mathrm{KS}$ & 8 & & & \\
\hline & & $\mathrm{S}$ & 39 & & & \\
\hline & & SS & 53 & & & \\
\hline \multicolumn{4}{|c|}{ Total } & 837 & $83,7 \%$ & Baik \\
\hline
\end{tabular}

Dimensi desain memperoleh hasil yang baik seperti yang ditunjukkan pada tabel 12 . Tanggapan dari 71 responden mengenai dimensi desain adalah Ohayou memiliki display produk dan desain interior yang menarik. Display produk, khususnya untuk produk roti disajikan pada etalase sehingga konsumen dapat dengan mudah melihat produk. Selain itu, Ohayou memiliki tema desain interior yang unik (sangat baik) yaitu JapaneseScandinavian dengan tujuan memberikan kesan hangat dengan ornamen kayu.

Tabel 13. Dimensi Merek

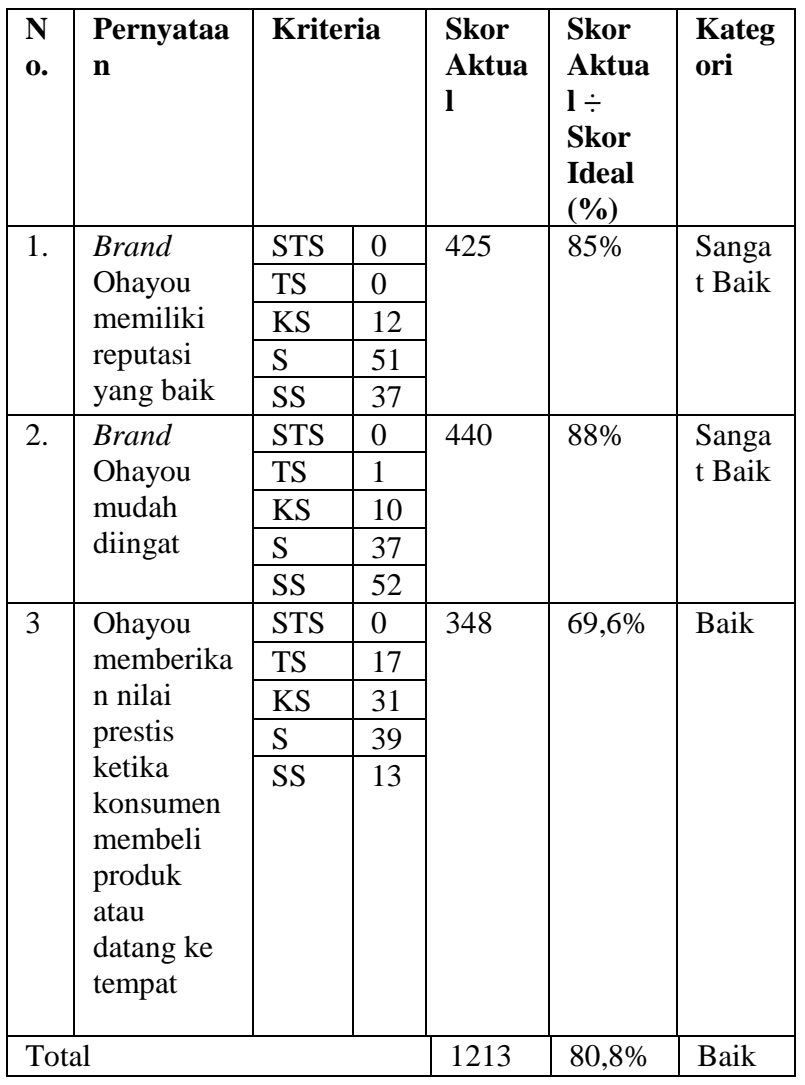

Pada tabel 13, hasil dari pengolahan data pada dimensi merek dikategorikan baik. Mayoritas responden yakni sebanyak $88 \%$ berpendapat Brand Ohayou memiliki reputasi yang sangat baik dan mudah diingat. Namun, berdasarkan indikator ketiga dari dimensi merek, 52\% responden menganggap Ohayou belum memberikan nilai prestis ketika mereka membeli produk atau datang ke tempat. Hal ini perlu diperhatikan oleh manajemen dan pemilik Ohayou. Pemilik dan manajemen Ohayou perlu memperhatikan dan merencanakan aspek-aspek yang dapat meningkatkan nilai prestige konsumen saat membeli produk Ohayou. 
Tabel 14. Dimensi Kemasan

\begin{tabular}{|c|c|c|c|c|c|c|}
\hline $\begin{array}{l}\mathbf{N} \\
\text { o. }\end{array}$ & $\begin{array}{l}\text { Pernyataa } \\
\text { n }\end{array}$ & \multicolumn{2}{|c|}{ Kriteria } & $\begin{array}{l}\text { Skor } \\
\text { Aktu } \\
\text { al }\end{array}$ & $\begin{array}{l}\text { Skor } \\
\text { Aktua } \\
1 \div \\
\text { Skor } \\
\text { Ideal } \\
(\%) \\
\end{array}$ & $\begin{array}{l}\text { Kate } \\
\text { gori }\end{array}$ \\
\hline \multirow[t]{5}{*}{1.} & \multirow{5}{*}{$\begin{array}{l}\text { Kemasan } \\
\text { produk } \\
\text { Ohayou } \\
\text { tidak } \\
\text { mudah } \\
\text { rusak }\end{array}$} & STS & 0 & \multirow[t]{5}{*}{393} & \multirow[t]{5}{*}{$78,6 \%$} & \multirow[t]{5}{*}{ Baik } \\
\hline & & TS & 0 & & & \\
\hline & & KS & 26 & & & \\
\hline & & $S$ & 55 & & & \\
\hline & & SS & 19 & & & \\
\hline \multirow[t]{5}{*}{2.} & \multirow{5}{*}{$\begin{array}{l}\text { Kemasan } \\
\text { produk } \\
\text { Ohayou } \\
\text { memiliki } \\
\text { tampilan } \\
\text { menarik }\end{array}$} & STS & 0 & \multirow[t]{5}{*}{386} & \multirow[t]{5}{*}{$77,2 \%$} & \multirow[t]{5}{*}{ Baik } \\
\hline & & TS & 5 & & & \\
\hline & & $\mathrm{KS}$ & 29 & & & \\
\hline & & $\mathrm{S}$ & 41 & & & \\
\hline & & SS & 25 & & & \\
\hline \multirow[t]{5}{*}{3.} & \multirow{5}{*}{$\begin{array}{l}\text { Kemasan } \\
\text { produk } \\
\text { Ohayou } \\
\text { membantu } \\
\text { konsumen } \\
\text { dalam } \\
\text { mengonsu } \\
\text { msi } \\
\text { produk } \\
\text { tersebut }\end{array}$} & STS & 0 & \multirow[t]{5}{*}{415} & \multirow[t]{5}{*}{$83 \%$} & \multirow[t]{5}{*}{ Baik } \\
\hline & & $\mathrm{TS}$ & 3 & & & \\
\hline & & $\mathrm{KS}$ & 12 & & & \\
\hline & & $\mathrm{S}$ & 52 & & & \\
\hline & & SS & 33 & & & \\
\hline \multicolumn{4}{|c|}{ Total } & 1194 & $79,6 \%$ & Baik \\
\hline
\end{tabular}

Terkait dengan pengolahan data untuk dimensi kemasan, seperti yang ditunjukkan pada tabel 14, sebanyak 74 responden menganggap kemasan produk Ohayou tidak mudah rusak. Namun, respon yang kurang setuju dengan pernyataan tersebut cukup banyak yakni sekitar $26 \%$ dari 100 responden. Hal ini dikarenakan kemasan yang digunakan untuk produk minuman antara lain berbahan kaca, keramik, plastik, atau paper cup. Beberapa bahan diantaranya mudah pecah atau rusak. Untuk produk makanan, Ohayou menggunakan piring keramik dan paper bag. Paper bag sendiri digunakan Ohayou dengan tujuan mengurangi limbah walaupun rentan terhadap air. Mayoritas responden yaitu 85 responden menganggap produk Ohayou memiliki tampilan menarik dan membantu konsumen dalam mengonsumsi produk tersebut.

Tabel 15. Rekapitulasi Tanggapan Responden Terhadap Variabel Atribut Produk Ohayou Bandung

\begin{tabular}{|l|l|l|l|}
\hline \multicolumn{1}{|c|}{ Dimensi } & \multicolumn{1}{c|}{$\begin{array}{c}\text { Skor } \\
\text { Aktual }\end{array}$} & $\begin{array}{c}\text { Skor } \\
\text { Aktual } \\
\text { Skor Ideal } \\
(\%)\end{array}$ & $\begin{array}{c}\text { Kateg } \\
\text { ori }\end{array}$ \\
\hline Kualitas & 1975 & $79 \%$ & Baik \\
\hline Fitur & 1134 & $75,6 \%$ & Baik \\
\hline Desain & 837 & $83,7 \%$ & Baik \\
\hline Merek & 1213 & $80,8 \%$ & Baik \\
\hline Kemasan & 1194 & $79,6 \%$ & Baik \\
\hline
\end{tabular}

\begin{tabular}{|l|l|l|l|}
\hline $\begin{array}{l}\text { Total Variabel } \\
\text { Atribut } \\
\text { Produk }\end{array}$ & 6353 & $79,4 \%$ & Baik \\
\hline
\end{tabular}

Tabel 15 menunjukkan hasil tanggapan responden atas variabel atribut produk. Semua dimensi dalam variabel atribut produk termasuk dalam kategori rata-rata baik. Hal ini menunjukkan bahwa atribut produk yang diberikan oleh Ohayou sudah baik, namun masih dapat ditingkatkan agar dapat naik ke kategori sangat baik. Adapun berdasarkan hasil tersebut, penilaian terendah terdapat pada dimensi fitur. Oleh karena itu, Ohayou perlu untuk meningkatkan fitur produknya, fitur produk yang dimaksud antara lain : varian menu, kualitas produk (lebih disesuaikan dengan selera konsumen) dan lain sebagainya.

\section{Distribusi Frekuensi Kualitas Pelayanan}

Variabel kualitas pelayanan terdiri dari 5 dimensi yaitu kehandalan, daya tanggap, jaminan, empati, dan bukti fisik. Setiap dimensi terdiri dari beberapa indikator yang digunakan untuk melihat hasil penilaian responden atas dimensi dari variabel kualitas pelayanan. 100 responden memberikan tanggapan atas 16 pernyataan mengenai indikator kualitas pelayanan tersebut.

Tabel 16 di bawah ini menunjukkan hasil pengolahan data untuk dimensi kehandalan. Hasil dimensi kehandalan dikategorikan sangat baik dengan persentase sebesar 86,5\%. Mayoritas responden yakni 97 responden beranggapan bahwa karyawan Ohayou memiliki kemampuan memadai dalam membuat minuman dan makanan, mampu menjelaskan menu dengan baik, dan mengantar pesanan yang sesuai kepada konsumen. Karyawan Ohayou diberikan training yang baik untuk barista dan runner sehingga kemampuan dan pengetahuan mereka mengenai produk cukup baik. 
Tabel 16. Dimensi Kehandalan

\begin{tabular}{|c|c|c|c|c|c|c|}
\hline $\begin{array}{l}\mathbf{N} \\
\mathbf{o} .\end{array}$ & Pernyataan & \multicolumn{2}{|c|}{ Kriteria } & $\begin{array}{l}\text { Skor } \\
\text { Akt } \\
\text { ual }\end{array}$ & $\begin{array}{l}\text { Skor } \\
\text { Aktua } \\
1 \div \\
\text { Skor } \\
\text { Ideal } \\
(\%)\end{array}$ & $\begin{array}{l}\text { Kat } \\
\text { egor } \\
\text { i }\end{array}$ \\
\hline \multirow[t]{5}{*}{1.} & \multirow{5}{*}{$\begin{array}{l}\text { Kemampuan } \\
\text { karyawan } \\
\text { Ohayou } \\
\text { memadai } \\
\text { dalam } \\
\text { membuat } \\
\text { minuman } \\
\text { dan } \\
\text { makanan }\end{array}$} & STS & 0 & \multirow[t]{5}{*}{422} & \multirow[t]{5}{*}{$84,4 \%$} & \multirow{5}{*}{$\begin{array}{l}\text { San } \\
\text { gat } \\
\text { Baik }\end{array}$} \\
\hline & & TS & 0 & & & \\
\hline & & $\mathrm{KS}$ & 3 & & & \\
\hline & & S & 63 & & & \\
\hline & & SS & 34 & & & \\
\hline \multirow[t]{5}{*}{2.} & \multirow{5}{*}{$\begin{array}{l}\text { Karyawan } \\
\text { Ohayou } \\
\text { mampu } \\
\text { menjelaskan } \\
\text { menu } \\
\text { dengan baik }\end{array}$} & STS & 0 & \multirow[t]{5}{*}{425} & \multirow[t]{5}{*}{$85 \%$} & \multirow{5}{*}{$\begin{array}{l}\text { San } \\
\text { gat } \\
\text { Baik }\end{array}$} \\
\hline & & $\mathrm{TS}$ & 0 & & & \\
\hline & & $\mathrm{KS}$ & 13 & & & \\
\hline & & $\mathrm{S}$ & 49 & & & \\
\hline & & SS & 38 & & & \\
\hline \multirow[t]{5}{*}{3.} & \multirow{5}{*}{$\begin{array}{l}\text { Menu yang } \\
\text { diantar } \\
\text { sesuai } \\
\text { dengan yang } \\
\text { dipesan oleh } \\
\text { konsumen }\end{array}$} & STS & 0 & \multirow[t]{5}{*}{451} & \multirow[t]{5}{*}{$90,2 \%$} & \multirow{5}{*}{$\begin{array}{l}\text { San } \\
\text { gat } \\
\text { Baik }\end{array}$} \\
\hline & & $\mathrm{TS}$ & 0 & & & \\
\hline & & $\mathrm{KS}$ & 2 & & & \\
\hline & & S & 45 & & & \\
\hline & & SS & 53 & & & \\
\hline \multicolumn{4}{|c|}{ Total } & 1298 & $86,5 \%$ & $\begin{array}{c}\text { San } \\
\text { gat } \\
\text { Baik }\end{array}$ \\
\hline
\end{tabular}

Tabel 17. Dimensi Daya Tanggap

\begin{tabular}{|c|c|c|c|c|c|c|}
\hline $\begin{array}{l}\mathbf{N} \\
\text { o. }\end{array}$ & Pernyataan & \multicolumn{2}{|c|}{ Kriteria } & $\begin{array}{l}\text { Sko } \\
\text { r } \\
\text { Akt } \\
\text { ual }\end{array}$ & $\begin{array}{l}\text { Skor } \\
\text { Aktua } \\
1 \square \\
\text { Skor } \\
\text { Ideal } \\
(\%)\end{array}$ & $\begin{array}{l}\text { Kateg } \\
\text { ori }\end{array}$ \\
\hline \multirow[t]{5}{*}{1.} & \multirow{5}{*}{$\begin{array}{l}\text { Karyawan } \\
\text { Ohayou } \\
\text { cepat } \\
\text { tanggap saat } \\
\text { melayani } \\
\text { konsumen }\end{array}$} & STS & 0 & \multirow[t]{5}{*}{414} & \multirow[t]{5}{*}{$82,8 \%$} & \multirow[t]{5}{*}{ Baik } \\
\hline & & TS & 0 & & & \\
\hline & & KS & 20 & & & \\
\hline & & S & 46 & & & \\
\hline & & SS & 34 & & & \\
\hline \multirow[t]{5}{*}{2.} & \multirow{5}{*}{$\begin{array}{l}\text { Karyawan } \\
\text { Ohayou } \\
\text { menyelesaik } \\
\text { an keluhan } \\
\text { dengan } \\
\text { sigap }\end{array}$} & STS & 0 & \multirow[t]{5}{*}{383} & \multirow[t]{5}{*}{$76,6 \%$} & \multirow[t]{5}{*}{ Baik } \\
\hline & & TS & 5 & & & \\
\hline & & $\mathrm{KS}$ & 26 & & & \\
\hline & & $\mathrm{S}$ & 50 & & & \\
\hline & & SS & 19 & & & \\
\hline \multicolumn{4}{|c|}{ Total } & 797 & $79.7 \%$ & Baik \\
\hline
\end{tabular}

Dimensi daya tanggap dikategorikan baik dengan persentase sebesar $79,7 \%$ seperti yang ditunjukkan oleh tabel 17. Sebanyak $80 \%$ responden berpendapat bahwa karyawan Ohayou cepat tanggap saat melayani konsumen dan dapat menyelesaikan keluhan dengan sigap. Salah satu faktor pendukung atas pernyataan ini adalah desain bar dan kasir yang dekat dengan konsumen sehingga karyawan Ohayou dapat segera melayani konsumen.
Tabel 18. Dimensi Jaminan

\begin{tabular}{|c|c|c|c|c|c|c|}
\hline $\begin{array}{l}\mathbf{N} \\
\text { o. }\end{array}$ & Pernyataan & \multicolumn{2}{|c|}{ Kriteria } & $\begin{array}{l}\text { Skor } \\
\text { Aktua } \\
\text { l }\end{array}$ & $\begin{array}{l}\text { Skor } \\
\text { Aktua } \\
1 \square \\
\text { Skor } \\
\text { Ideal } \\
(\%)\end{array}$ & $\begin{array}{l}\text { Kat } \\
\text { egor } \\
\text { i }\end{array}$ \\
\hline \multirow[t]{5}{*}{1.} & \multirow{5}{*}{$\begin{array}{l}\text { Ohayou } \\
\text { berupaya } \\
\text { menjaga } \\
\text { kenyamanan } \\
\text { konsumen } \\
\text { yang } \\
\text { berkunjung }\end{array}$} & STS & 0 & \multirow[t]{5}{*}{404} & \multirow[t]{5}{*}{$80,8 \%$} & \multirow[t]{5}{*}{ Baik } \\
\hline & & TS & 1 & & & \\
\hline & & $\mathrm{KS}$ & 21 & & & \\
\hline & & $\mathrm{S}$ & 51 & & & \\
\hline & & SS & 27 & & & \\
\hline \multirow[t]{5}{*}{2.} & \multirow{5}{*}{$\begin{array}{l}\text { Transaksi } \\
\text { dilakukan } \\
\text { dengan } \\
\text { tepat sesuai } \\
\text { dengan } \\
\text { perhitungan } \\
\text { tagihan }\end{array}$} & STS & 0 & \multirow[t]{5}{*}{462} & \multirow[t]{5}{*}{$92,4 \%$} & \multirow{5}{*}{$\begin{array}{l}\text { San } \\
\text { gat } \\
\text { Baik }\end{array}$} \\
\hline & & TS & 0 & & & \\
\hline & & $\mathrm{KS}$ & 0 & & & \\
\hline & & $\mathrm{S}$ & 38 & & & \\
\hline & & SS & 62 & & & \\
\hline \multirow[t]{5}{*}{3.} & \multirow{5}{*}{$\begin{array}{l}\text { Transaksi } \\
\text { dilakukan } \\
\text { dengan } \\
\text { aman }\end{array}$} & STS & 0 & \multirow[t]{5}{*}{465} & \multirow[t]{5}{*}{$93 \%$} & \multirow{5}{*}{$\begin{array}{l}\text { San } \\
\text { gat } \\
\text { Baik }\end{array}$} \\
\hline & & TS & 0 & & & \\
\hline & & KS & 1 & & & \\
\hline & & $\mathrm{S}$ & 33 & & & \\
\hline & & SS & 66 & & & \\
\hline \multirow[t]{5}{*}{4.} & \multirow{5}{*}{$\begin{array}{l}\text { Konsumen } \\
\text { merasa } \\
\text { yakin akan } \\
\text { kehalalan } \\
\text { produk yang } \\
\text { dijual } \\
\text { Ohayou } \\
\end{array}$} & STS & 0 & \multirow[t]{5}{*}{422} & \multirow[t]{5}{*}{$84,4 \%$} & \multirow{5}{*}{$\begin{array}{l}\text { San } \\
\text { gat } \\
\text { Baik }\end{array}$} \\
\hline & & TS & 0 & & & \\
\hline & & $\mathrm{KS}$ & 11 & & & \\
\hline & & $\mathrm{S}$ & 56 & & & \\
\hline & & SS & 33 & & & \\
\hline \multicolumn{4}{|c|}{ Total } & 1753 & $87,6 \%$ & $\begin{array}{c}\text { San } \\
\text { gat } \\
\text { Baik }\end{array}$ \\
\hline
\end{tabular}

Bila melihat pada tabel 18 dapat disimpulkan bahwa dimensi jaminan memiliki hasil yang sangat baik dengan persentase sebesar $87,6 \%$. Sebanyak 78 responden menganggap Ohayou berupaya menjaga kenyamanan konsumen yang berkunjung. Selain menyajikan produk, karyawan Ohayou juga bertugas untuk memerhatikan kenyamanan konsumen dengan memberikan password wifi, free-flow air mineral, dan menawarkan kursi tambahan saat dibutuhkan. Responden berpendapat transaksi yang dilakukan di Ohayou tepat sesuai tagihan dan aman. Ohayou menyediakan berbagai macam metode pembayaran yaitu dengan cash, kartu debit, kartu kredit, gopay, dan dana. Sebanyak 89 responden merasa yakin akan kehandalan produk Ohayou karena bahanbahan yang digunakan dijual dipasaran dan konsumen dapat dengan jelas melihat karyawan Ohayou menyajikan minuman. 
Tabel 19. Dimensi Empati

\begin{tabular}{|c|c|c|c|c|c|c|}
\hline No. & $\begin{array}{l}\text { Pernyata } \\
\text { an }\end{array}$ & \multicolumn{2}{|c|}{ Kriteria } & $\begin{array}{l}\text { Skor } \\
\text { Aktua } \\
\text { l }\end{array}$ & $\begin{array}{l}\text { Skor } \\
\text { Aktual } \\
\square \\
\text { Skor } \\
\text { Ideal } \\
(\%)\end{array}$ & $\begin{array}{l}\text { Kateg } \\
\text { ori }\end{array}$ \\
\hline \multirow[t]{5}{*}{1.} & \multirow{5}{*}{$\begin{array}{l}\text { Karyawan } \\
\text { Ohayou } \\
\text { melayani } \\
\text { dengan } \\
\text { sopan dan } \\
\text { ramah }\end{array}$} & STS & 0 & \multirow[t]{5}{*}{439} & \multirow[t]{5}{*}{$87,8 \%$} & \multirow{5}{*}{$\begin{array}{l}\text { Sangat } \\
\text { Baik }\end{array}$} \\
\hline & & TS & 0 & & & \\
\hline & & KS & 4 & & & \\
\hline & & $S$ & 53 & & & \\
\hline & & SS & 43 & & & \\
\hline \multirow[t]{5}{*}{2.} & \multirow{5}{*}{$\begin{array}{l}\text { Karyawan } \\
\text { Ohayou } \\
\text { menangga } \\
\text { pi kritik } \\
\text { dan saran } \\
\text { yang } \\
\text { diberikan } \\
\text { dengan } \\
\text { baik }\end{array}$} & STS & 0 & \multirow[t]{5}{*}{398} & \multirow[t]{5}{*}{$79,6 \%$} & \multirow[t]{5}{*}{ Baik } \\
\hline & & TS & 4 & & & \\
\hline & & $\mathrm{KS}$ & 20 & & & \\
\hline & & $\mathrm{S}$ & 50 & & & \\
\hline & & SS & 26 & & & \\
\hline \multirow[t]{5}{*}{3.} & \multirow{5}{*}{$\begin{array}{l}\text { Karyawan } \\
\text { Ohayou } \\
\text { memaham } \\
\text { i } \\
\text { kebutuhan } \\
\text { konsumen } \\
\text { dengan } \\
\text { baik }\end{array}$} & STS & 0 & \multirow[t]{5}{*}{399} & \multirow[t]{5}{*}{$79,8 \%$} & \multirow[t]{5}{*}{ Baik } \\
\hline & & TS & 1 & & & \\
\hline & & $\mathrm{KS}$ & 30 & & & \\
\hline & & $S$ & 38 & & & \\
\hline & & SS & 31 & & & \\
\hline \multicolumn{4}{|c|}{ Total } & 1236 & $82,4 \%$ & Baik \\
\hline
\end{tabular}

Responden menilai bahwa empati yang dimiliki oleh karyawan Ohayou termasuk dalam kategori baik, dimana angka 82,4\% menunjukkan banyaknya penilaian baik dan sangat baik terhadap indikator empati (seperti yang tertera pada tabel 19). Mayoritas responden yakni 96 responden beranggapan bahwa karyawan Ohayou bersikap sopan dan ramah. Karyawan Ohayou wajib untuk bersikap sopan kepada setiap konsumen yang berkunjung dan bersikap ramah seperti teman.

Sikap empati ini merupakan prinsip yang diterapkan oleh Ohayou sedari awal, empati bertujuan agar tercipta hubungan yang akrab antara karyawan dan konsumen Ohayou. Namun berdasarkan hasil tersebut, dapat disimpulkan bahwa karyawan Ohayou sebaiknya meningkatkan kemampuannya untuk menerima kritik dan saran, serta kemampuannya untuk memahami kebutuhan konsumen, sehingga kedepannya, Ohayou dapat memperoleh nilai sangat baik untuk semua indikator empati.
Tabel 20. Dimensi Bukti Fisik

\begin{tabular}{|c|c|c|c|c|c|c|}
\hline $\begin{array}{l}\mathbf{N} \\
\mathbf{0 .}\end{array}$ & $\begin{array}{l}\text { Pernyat } \\
\text { aan }\end{array}$ & \multicolumn{2}{|c|}{ Kriteria } & $\begin{array}{l}\text { Skor } \\
\text { Aktua }\end{array}$ & $\begin{array}{l}\text { Skor } \\
\text { Aktua }\end{array}$ & $\begin{array}{l}\text { Kateg } \\
\text { ori }\end{array}$ \\
\hline \multirow[t]{5}{*}{1} & \multirow{5}{*}{$\begin{array}{l}\text { Karyaw } \\
\text { an } \\
\text { Ohayou } \\
\text { berpakai } \\
\text { an rapi } \\
\text { dan } \\
\text { sopan }\end{array}$} & STS & 0 & \multirow[t]{5}{*}{430} & \multirow[t]{5}{*}{$86 \%$} & \multirow{5}{*}{$\begin{array}{l}\text { Sangat } \\
\text { Baik }\end{array}$} \\
\hline & & TS & 1 & & & \\
\hline & & KS & 11 & & & \\
\hline & & $\mathrm{S}$ & 45 & & & \\
\hline & & SS & 43 & & & \\
\hline \multirow[t]{5}{*}{2.} & \multirow{5}{*}{$\begin{array}{l}\text { Ruanga } \\
\mathrm{n} \\
\text { Ohayou } \\
\text { selalu } \\
\text { dalam } \\
\text { keadaan } \\
\text { bersih } \\
\text { dan } \\
\text { nyaman }\end{array}$} & STS & 0 & \multirow[t]{5}{*}{416} & \multirow[t]{5}{*}{$83,2 \%$} & \multirow[t]{5}{*}{ Baik } \\
\hline & & TS & 3 & & & \\
\hline & & KS & 10 & & & \\
\hline & & $\mathrm{S}$ & 55 & & & \\
\hline & & SS & 32 & & & \\
\hline 3. & \multirow{5}{*}{$\begin{array}{l}\text { Fasilitas } \\
\text { yang } \\
\text { disediak } \\
\text { an } \\
\text { Ohayou } \\
\text { selalu } \\
\text { dalam } \\
\text { keadaan } \\
\text { bersih } \\
\text { dan baik }\end{array}$} & STS & 0 & \multirow[t]{5}{*}{405} & \multirow[t]{5}{*}{$81 \%$} & \multirow[t]{5}{*}{ Baik } \\
\hline & & TS & 2 & & & \\
\hline & & $\mathrm{KS}$ & 16 & & & \\
\hline & & S & 57 & & & \\
\hline & & SS & 25 & & & \\
\hline \multirow[t]{5}{*}{4.} & \multirow{5}{*}{$\begin{array}{l}\text { Ohayou } \\
\text { menggu } \\
\text { nakan } \\
\text { mesin } \\
\text { yang } \\
\text { modern } \\
\text { untuk } \\
\text { membua } \\
\text { t kopi }\end{array}$} & STS & 0 & \multirow[t]{5}{*}{433} & \multirow[t]{5}{*}{$86,6 \%$} & \multirow{5}{*}{$\begin{array}{l}\text { Sangat } \\
\text { Baik }\end{array}$} \\
\hline & & TS & 1 & & & \\
\hline & & $\mathrm{KS}$ & 7 & & & \\
\hline & & $\mathrm{S}$ & 50 & & & \\
\hline & & SS & 42 & & & \\
\hline \multicolumn{4}{|c|}{ Total } & 1684 & $84,2 \%$ & $\begin{array}{c}\text { Sangat } \\
\text { Baik }\end{array}$ \\
\hline
\end{tabular}

Hasil pada dimensi bukti fisik atau tangibles ditunjukkan pada tabel 20. Dimensi bukti fisik dikategorikan sangat baik dengan persentase sebesar 84,2\%. Sebanyak $86 \%$ responden menganggap bahwa karyawan Ohayou berpakaian rapi dan sopan, ruangan dan fasilitas yang disediakan selalu dalam keadaan bersih dan baik, serta mesin modern yang digunakan Ohayou. Berdasarkan hasil penilaian responden, perusahaan dapat meningkatkan kebersihan ruangan dan fasilitas sehingga ke depannya dapat dinilai sangat baik oleh pengunjung Ohayou. 
Tabel 21. Penggunaan Fasilitas Ohayou oleh Responden

\begin{tabular}{|l|c|c|}
\hline \multicolumn{1}{|c|}{ Fasilitas } & Frekuensi & Persentase \\
\hline Free wifi & 87 & $21,17 \%$ \\
\hline Free-flow air mineral & 66 & $16,06 \%$ \\
\hline Stop kontak & 64 & $15,57 \%$ \\
\hline Kursi tambahan & 43 & $10,46 \%$ \\
\hline Pembayaran elektronik & 66 & $16,06 \%$ \\
\hline Toilet & 46 & $11,19 \%$ \\
\hline Tempat parkir & 39 & $9,49 \%$ \\
\hline Total & 411 & $100 \%$ \\
\hline
\end{tabular}

Tabel 21 menunjukkan fasilitas yang disediakan oleh Ohayou serta tanggapan responden atas Fasilitas yang disediakan. Berdasarkan tabel 21, fasilitas "Free Wifi" merupakan fasilitas yang paling banyak digunakan oleh responden. Dimana sebanyak $21,17 \%$ responden menggunakan fasilitas tersebut, persentase ini lebih banyak dibandingkan dengan penggunaan fasilitas lain. Jika dilihat dari frekuensi penggunaan fasilitas free wifi, sebanyak 87 responden dari 100 responden menggunakan fasilitas ini.

Tabel 22. Tanggapan Responden Terhadap Variabel Kualitas Pelayanan Ohayou Bandung

\begin{tabular}{|l|l|l|l|}
\hline Dimensi & $\begin{array}{l}\text { Skor } \\
\text { Aktual }\end{array}$ & $\begin{array}{l}\text { Skor } \\
\text { Aktual } \\
\div \text { Skor } \\
\text { Ideal } \\
(\boldsymbol{\%})\end{array}$ & Kategori \\
\hline Kehandalan & 1298 & $86,5 \%$ & Sangat Baik \\
\hline Daya Tanggap & 797 & $79,7 \%$ & Baik \\
\hline Jaminan & 1753 & $87,6 \%$ & Sangat Baik \\
\hline Empati & 1236 & $82,4 \%$ & Baik \\
\hline Bukti Fisik & 1684 & $84,2 \%$ & Sangat Baik \\
\hline $\begin{array}{l}\text { Total: Variabel } \\
\text { Kualitas Pelayanan }\end{array}$ & 6768 & $84,6 \%$ & Sangat Baik \\
\hline
\end{tabular}

Rekapitulasi dalam tabel 22 menunjukkan bahwa hasil penilaian terhadap variabel kualitas pelayanan dapat dikategorikan sangat baik. Variabel kualitas pelayanan memiliki persentase sebesar $84,6 \%$. Terdapat 3 dimensi yang dikategorikan sangat baik, yaitu kehandalan, jaminan, dan bukti fisik. Secara keseluruhan, responden memberikan respon positif kepada kelima dimensi dari kualitas pelayanan Ohayou.

\section{Distribusi Frekuensi Proses Keputusan Pembelian}

Variabel proses pengambilan keputusan pembelian memiliki 5 dimensi, yaitu pengenalan masalah, pencarian informasi, evaluasi alternatif, keputusan pembelian, dan perilaku pasca pembelian. Terdapat tanggapan dari 100 responden atas 12 pernyataan mengenai variabel keputusan pembelian seperti diuraikan tabel-tabel di bawah ini.

Tabel 23. Dimensi Pengenalan Masalah

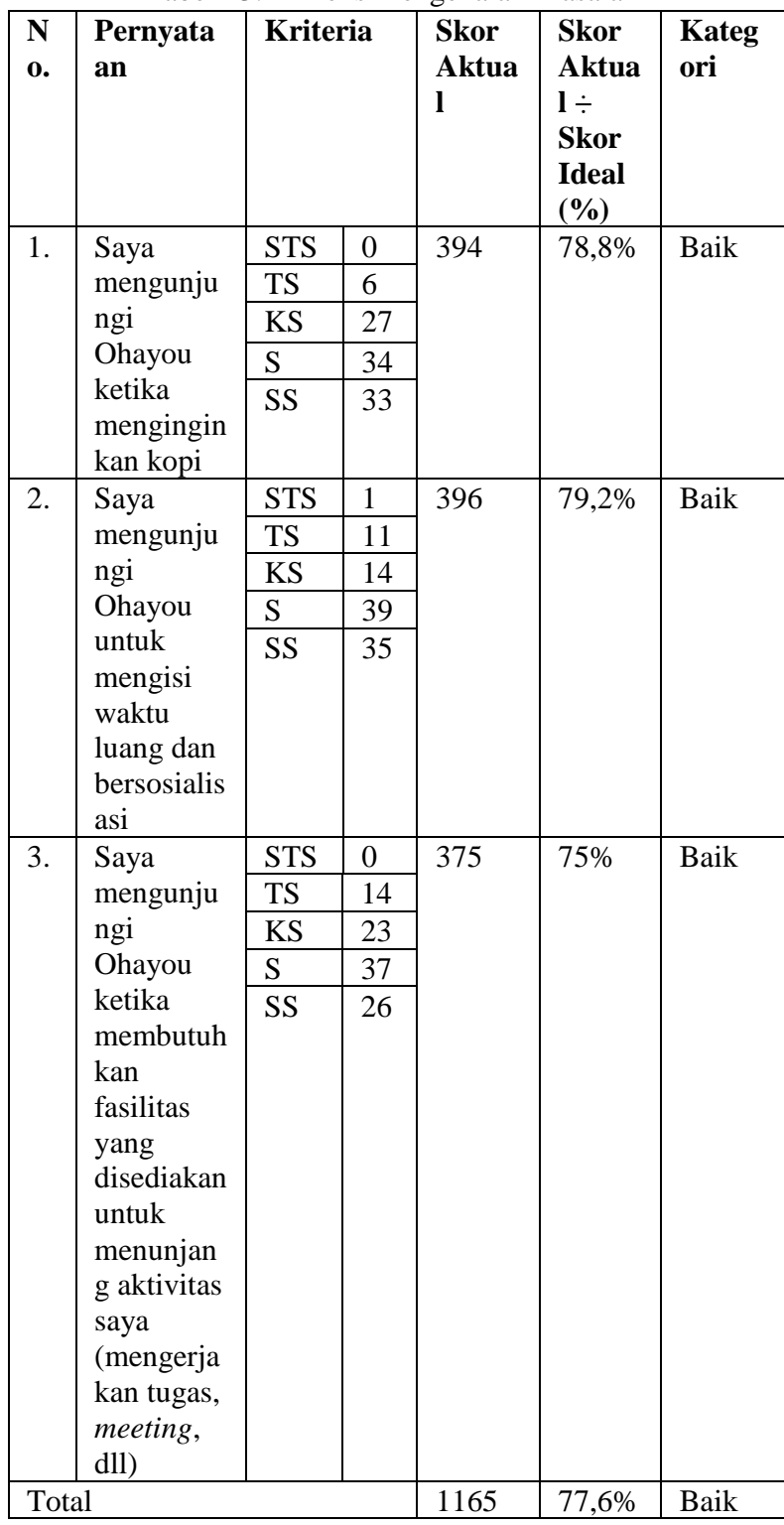

Dari tabel 23 diperoleh hasil skor untuk dimensi pengenalan masalah sebesar 77,6\% yang termasuk dalam kategori baik. Mayoritas responden mengunjungi Ohayou ketika menginginkan kopi, mengisi waktu luang atau bersosialisasi, dan ketika membutuhkan fasilitas yang disediakan. Namun terdapat beberapa responden yang kurang setuju akan ketiga pernyataan tersebut yakni sekitar $25 \%$, hal ini dipengaruhi banyaknya jumlah kedai kopi di daerah Ciumbuleuit Bandung yang dapat dijadikan tempat memperoleh kopi, mengisi waktu luang dan bersosialisasi, serta memperoleh fasilitas. Hal ini juga disebabkan oleh preferensi masing-masing konsumen yang berbeda-beda. 
Tabel 24. Dimensi Pencarian Informasi

\begin{tabular}{|c|c|c|c|c|c|c|}
\hline $\begin{array}{l}\mathbf{N} \\
\text { o. }\end{array}$ & $\begin{array}{l}\text { Pernyata } \\
\text { an }\end{array}$ & \multicolumn{2}{|c|}{ Kriteria } & $\begin{array}{l}\text { Sko } \\
\text { r } \\
\text { Akt } \\
\text { ual }\end{array}$ & $\begin{array}{l}\text { Skor } \\
\text { Aktua } \\
1 \square \\
\text { Skor } \\
\text { Ideal } \\
(\%)\end{array}$ & $\begin{array}{l}\text { Kat } \\
\text { egor } \\
\text { i }\end{array}$ \\
\hline \multirow[t]{5}{*}{1.} & \multirow{5}{*}{$\begin{array}{l}\text { Saya } \\
\text { memperol } \\
\text { eh } \\
\text { informasi } \\
\text { mengenai } \\
\text { Ohayou } \\
\text { dari teman } \\
\text { atau relasi }\end{array}$} & STS & 3 & \multirow[t]{5}{*}{423} & \multirow[t]{5}{*}{$84,6 \%$} & \multirow{5}{*}{$\begin{array}{l}\text { San } \\
\text { gat } \\
\text { Baik }\end{array}$} \\
\hline & & TS & 2 & & & \\
\hline & & KS & 9 & & & \\
\hline & & $S$ & 41 & & & \\
\hline & & SS & 45 & & & \\
\hline \multirow[t]{5}{*}{2.} & \multirow{5}{*}{$\begin{array}{l}\text { Saya } \\
\text { memperol } \\
\text { eh } \\
\text { informasi } \\
\text { mengenai } \\
\text { Ohayou } \\
\text { dari social } \\
\text { media }\end{array}$} & STS & 7 & \multirow[t]{5}{*}{323} & \multirow[t]{5}{*}{$64,6 \%$} & \multirow{5}{*}{$\begin{array}{l}\text { Kur } \\
\text { ang } \\
\text { Baik }\end{array}$} \\
\hline & & TS & 23 & & & \\
\hline & & KS & 28 & & & \\
\hline & & S & 24 & & & \\
\hline & & SS & 18 & & & \\
\hline \multicolumn{4}{|c|}{ Total } & 746 & $74,6 \%$ & Baik \\
\hline
\end{tabular}

Tabel 24 menunjukkan hasil responden terhadap dimensi pencarian informasi. Dimensi pencarian informasi dapat dikategorikan baik dengan hasil persentase sebesar $74,6 \%$. Sebanyak $84,6 \%$ responden memperoleh informasi mengenai Ohayou dari teman atau relasi. Namun, sebanyak $64,6 \%$ responden yang tidak setuju dan kurang setuju atas pernyataan bahwa responden memperoleh informasi mengenai Ohayou dari social media. Hal ini dikarenakan mayoritas responden adalah mahasiswa UNPAR sehingga umumnya mereka tidak memperoleh informasi dari social media tapi informasi diperoleh karena mereka melalui atau mengakses jalan yang dekat dengan Ohayou. Karena akses yang dekat tersebut (sering dilalui), umumnya responden langsung mencoba Ohayou tanpa mencari informasi terlebih dahulu.

Pada tabel 25, hasil untuk dimensi evaluasi alternatif dikategorikan baik. Mayoritas responden berpendapat bahwa produk dan fasilitas yang disediakan Ohayou lebih baik dari kedai kopi lain di sekitar Ciumbuleuit. Namun, ada sekitar 30\% responden yang berpendapat bahwa produk dan fasilitas Ohayou tidak lebih baik dibanding kedai kopi lain. Berdasarkan hasil pengamatan, hal ini disebabkan oleh keterbatasan ruang yang dimiliki Ohayou sehingga tidak dapat menampung kapasitas konsumen yang besar. Hal ini menyebabkan Ohayou kurang cocok untuk kegiatan komunal seperti meeting atau kerja kelompok. Di sisi lain sekitar $76,4 \%$ responden beranggapan bahwa membeli di Ohayou lebih menguntungkan dibanding kedai kopi lain.

Tabel 25. Dimensi Evaluasi Alternatif

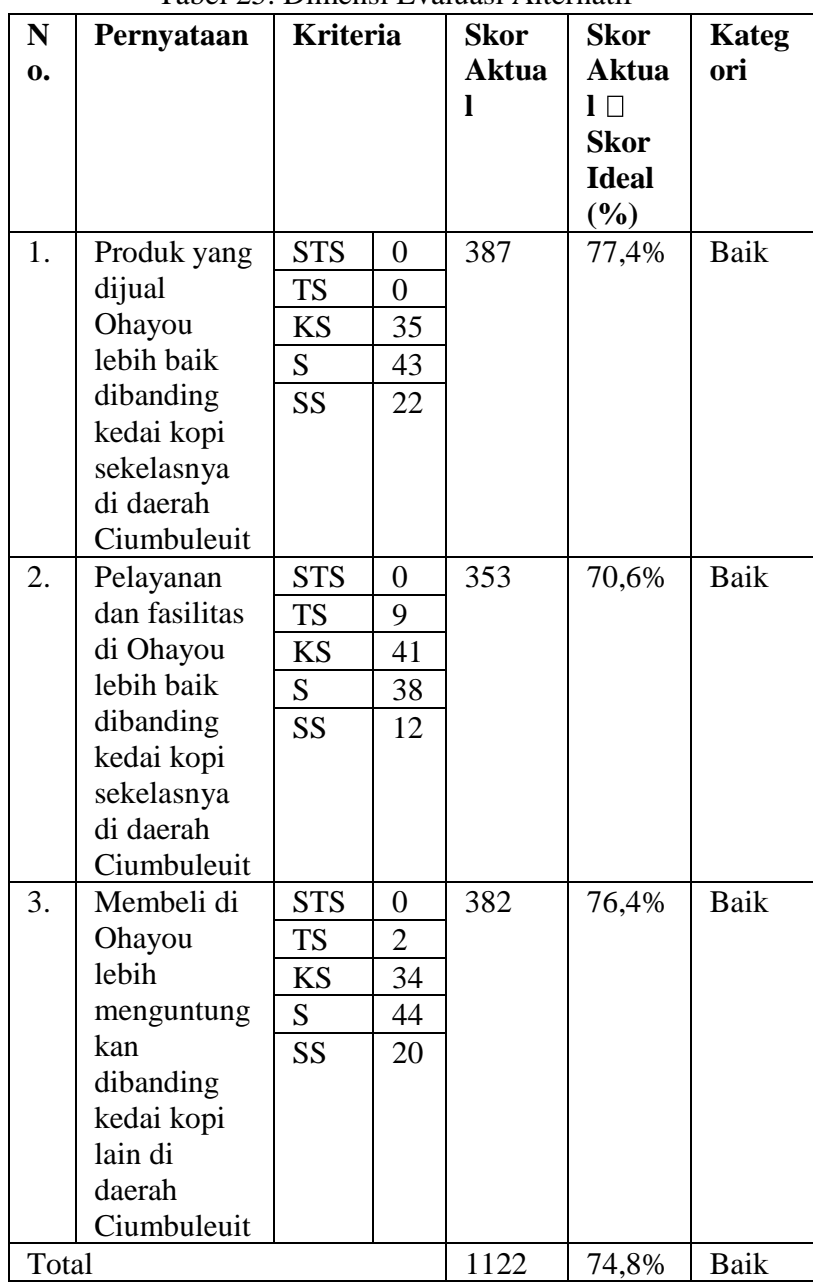

Tabel 26 menunjukkan bahwa dimensi keputusan pembelian mendapatkan persentase nilai sangat baik yakni sebesar $84,2 \%$. Hal ini menunjukkan bahwa mayoritas responden memutuskan untuk membeli produk Ohayou atas preferensinya sendiri dan merasa keputusan mereka adalah keputusan yang tepat. 
Tabel 26. Dimensi Keputusan Pembelian

\begin{tabular}{|c|c|c|c|c|c|c|}
\hline $\begin{array}{l}\mathbf{N} \\
\text { o. }\end{array}$ & Pernyataan & \multicolumn{2}{|c|}{ Kriteria } & $\begin{array}{l}\text { Sko } \\
\text { r } \\
\text { Akt } \\
\text { ual }\end{array}$ & $\begin{array}{l}\text { Sko } \\
\text { r } \\
\text { Akt } \\
\text { ual } \\
\square \\
\text { Sko } \\
\text { r } \\
\text { Idea } \\
\text { l } \\
(\%)\end{array}$ & $\begin{array}{l}\text { Kateg } \\
\text { ori }\end{array}$ \\
\hline \multirow[t]{5}{*}{1.} & \multirow{5}{*}{$\begin{array}{l}\text { Saya } \\
\text { memutuskan } \\
\text { untuk } \\
\text { membeli } \\
\text { produk } \\
\text { Ohayou atas } \\
\text { preferensi } \\
\text { saya } \\
\text { terhadap } \\
\text { produk dan } \\
\text { pelayananny } \\
\text { a }\end{array}$} & STS & 0 & \multirow[t]{5}{*}{420} & \multirow[t]{5}{*}{$84 \%$} & \multirow{5}{*}{$\begin{array}{l}\text { Sanga } \\
\text { t Baik }\end{array}$} \\
\hline & & TS & 0 & & & \\
\hline & & $\mathrm{KS}$ & 18 & & & \\
\hline & & $\mathrm{S}$ & 44 & & & \\
\hline & & SS & 38 & & & \\
\hline \multirow[t]{5}{*}{2.} & \multirow{5}{*}{$\begin{array}{l}\text { Saya merasa } \\
\text { keputusan } \\
\text { saya untuk } \\
\text { membeli di } \\
\text { Ohayou } \\
\text { adalah } \\
\text { keputusan } \\
\text { yang tepat }\end{array}$} & STS & 0 & \multirow[t]{5}{*}{422} & \multirow{5}{*}{$\begin{array}{l}84,4 \\
\%\end{array}$} & \multirow{5}{*}{$\begin{array}{l}\text { Sanga } \\
\text { t Baik }\end{array}$} \\
\hline & & TS & 1 & & & \\
\hline & & KS & 12 & & & \\
\hline & & $\mathrm{S}$ & 51 & & & \\
\hline & & SS & 36 & & & \\
\hline \multicolumn{4}{|c|}{ Total } & 842 & $\begin{array}{c}84,2 \\
\%\end{array}$ & $\begin{array}{c}\text { Sangat } \\
\text { Baik }\end{array}$ \\
\hline
\end{tabular}

Tabel 27. Dimensi Perilaku Pasca Pembelian

\begin{tabular}{|c|c|c|c|c|c|c|}
\hline $\begin{array}{l}\mathbf{N} \\
\text { o. }\end{array}$ & $\begin{array}{l}\text { Pernyat } \\
\text { aan }\end{array}$ & \multicolumn{2}{|c|}{ Kriteria } & $\begin{array}{l}\text { Skor } \\
\text { Aktua }\end{array}$ & $\begin{array}{l}\text { Skor } \\
\text { Aktua }\end{array}$ & $\begin{array}{l}\text { Katego } \\
\text { ri }\end{array}$ \\
\hline \multirow[t]{5}{*}{1.} & \multirow{5}{*}{$\begin{array}{l}\text { Saya } \\
\text { merasa } \\
\text { puas } \\
\text { setelah } \\
\text { melakuk } \\
\text { an } \\
\text { pembelia } \\
\text { n di } \\
\text { Ohayou }\end{array}$} & STS & 0 & \multirow[t]{5}{*}{429} & \multirow[t]{5}{*}{$85,8 \%$} & \multirow[t]{5}{*}{$\begin{array}{l}\text { Sangat } \\
\text { Baik }\end{array}$} \\
\hline & & TS & 0 & & & \\
\hline & & KS & 7 & & & \\
\hline & & $\mathrm{S}$ & 57 & & & \\
\hline & & SS & 36 & & & \\
\hline \multirow[t]{5}{*}{2.} & \multirow{5}{*}{$\begin{array}{l}\text { Saya } \\
\text { akan } \\
\text { membagi } \\
\text { kan } \\
\text { informas } \\
\text { i positif } \\
\text { mengena } \\
\text { i } \\
\text { pengala } \\
\text { man } \\
\text { saya } \\
\text { mengunj } \\
\text { ungi } \\
\text { Ohayou }\end{array}$} & STS & 0 & \multirow[t]{5}{*}{397} & \multirow[t]{5}{*}{$79,4 \%$} & \multirow[t]{5}{*}{ Baik } \\
\hline & & TS & 0 & & & \\
\hline & & KS & 27 & & & \\
\hline & & $S$ & 49 & & & \\
\hline & & SS & 24 & & & \\
\hline \multicolumn{4}{|c|}{ Total } & 826 & $82,6 \%$ & Baik \\
\hline
\end{tabular}

Tabel 27 menunjukkan bahwa dimensi perilaku pasca pembelian memperoleh skor $82,6 \%$ di mana mayoritas responden merasa puas setelah melakukan pembelian di Ohayou dan bersedia untuk membagikan informasi positif mengenai pengalaman pembelian mereka.

Tabel 28. Rekapitulasi Tanggapan Responden Terhadap Variabel Keputusan Pembelian Ohayou Bandung

\begin{tabular}{|l|l|l|l|}
\hline Dimensi & $\begin{array}{l}\text { Skor } \\
\text { Aktual }\end{array}$ & $\begin{array}{l}\text { Skor } \\
\text { Aktual } \\
\mathbf{6} \text { Skor } \\
\text { Ideal } \\
(\boldsymbol{\%})\end{array}$ & Kategori \\
\hline $\begin{array}{l}\text { Pengenalan } \\
\text { Masalah }\end{array}$ & 1165 & $77,6 \%$ & Baik \\
\hline $\begin{array}{l}\text { Pencarian } \\
\text { Informasi }\end{array}$ & 746 & $74,6 \%$ & Baik \\
\hline Evaluasi Alternatif & 1122 & $74,8 \%$ & Baik \\
\hline $\begin{array}{l}\text { Keputusan } \\
\text { Pembelian }\end{array}$ & 842 & $84,2 \%$ & Sangat Baik \\
\hline $\begin{array}{l}\text { Perilaku Pasca } \\
\text { Pembelian }\end{array}$ & 826 & $82,6 \%$ & Baik \\
\hline $\begin{array}{l}\text { Variabel Keputusan } \\
\text { Pembelian }\end{array}$ & 4701 & $78,3 \%$ & Baik \\
\hline
\end{tabular}

Tabel 28 merupakan hasil rekapitulasi dimensi dari variabel keputusan pembelian. Secara keseluruhan, variabel keputusan pembelian memperoleh hasil yang baik dengan persentase sebesar 78,4\%. Dimensi keputusan pembelian memiliki hasil tertinggi yakni sangat baik sebesar $84,2 \%$. Dapat dikatakan bahwa responden memberikan respon positif terhadap keputusan pembelian di Ohayou.

\section{Uji Normalitas}

\section{One-Sample Kolmogorov-Smirnov Test}

\begin{tabular}{llr} 
& & $\begin{array}{r}\text { Unstandardiz } \\
\text { ed Residual }\end{array}$ \\
\hline $\mathrm{N}$ & Mean & 100 \\
\hline Normal Parameters & a,b & .0000000 \\
\cline { 2 - 3 } & Std. Deviation & 4.45147860 \\
\hline $\begin{array}{l}\text { Most Extreme } \\
\text { Differences }\end{array}$ & Absolute & .046 \\
\cline { 2 - 3 } & Positive & .031 \\
\cline { 2 - 3 } & Negative & -.046 \\
\hline Test Statistic & & .046 \\
\hline Asymp. Sig. (2-tailed) & & $.200^{\mathrm{c}, \mathrm{d}}$ \\
\hline
\end{tabular}
a. Test distribution is Normal.
b. Calculated from data.
c. Lilliefors Significance Correction.
d. This is a lower bound of the true significance. 
Gambar 2 menunjukkan hasil uji OneSample Kolmogorov-Smirnov yang mana diperoleh nilai signifikansi sebesar 0,200. Hasil tersebut lebih besar dari 0,05 sehingga dapat disimpulkan bahwa data berdistribusi normal.

\section{Uji Heteroskedastisitas}

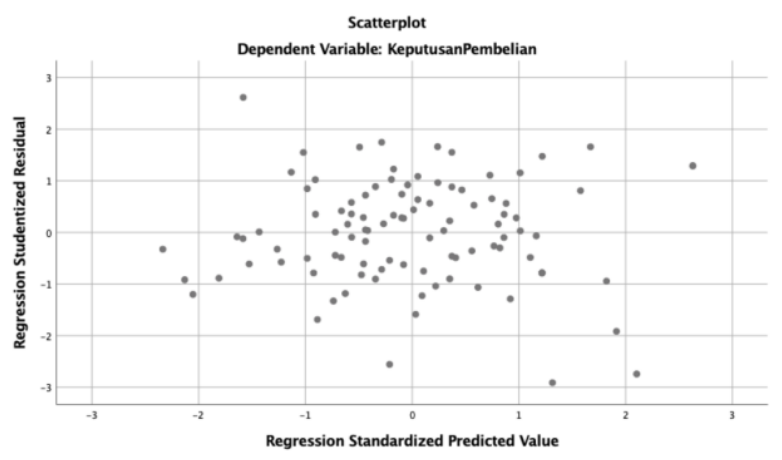

Gambar 3. Hasil Uji Heteroskedastisitas

Berdasarkan grafik pada Gambar 3, hasil scatterplot menunjukkan bahwa penyebaran data di atas dan di bawah angka 0 pada sumbu Y. Penyebaran titik tidak membentuk pola tertentu yang teratur sehingga dapat disimpulkan bahwa tidak terjadi heteroskedastisitas.

\section{Uji Korelasi Parsial}

\begin{tabular}{ll|r|r}
\multicolumn{2}{c}{ Correlations } & \\
& \multicolumn{1}{c}{$\begin{array}{c}\text { AtributProdu } \\
\mathrm{k}\end{array}$} & $\begin{array}{c}\text { KeputusanPe } \\
\text { mbelian }\end{array}$ \\
\hline AtributProduk & Pearson Correlation & 1 & $.527^{* *}$ \\
\cline { 2 - 4 } & Sig. (2-tailed) & & .000 \\
\cline { 2 - 4 } & $\mathrm{N}$ & 100 & 100 \\
\hline KeputusanPembelian & Pearson Correlation & $.527^{* *}$ & 1 \\
\cline { 2 - 4 } & Sig. (2-tailed) & .000 & \\
\cline { 2 - 4 } & $\mathrm{N}$ & 100 & 100 \\
\hline \multirow{2}{*}{ **. Correlation is significant at the 0.01 level (2-tailed). } \\
\hline
\end{tabular}

Gambar 4. Hasil Uji Korelasi Parsial X1

Berdasarkan gambar 4, nilai koefisien korelasi antara atribut produk dengan keputusan pembelian adalah sebesar 0,527. Maka dapat disimpulkan bahwa atribut produk dan proses pengambilan keputusan pembelian memiliki hubungan searah yang dikategorikan sedang. Hubungan searah menunjukkan jika atribut produk naik maka proses pengambilan keputusan pembelian juga akan naik

\begin{tabular}{ll|r|r} 
& \multicolumn{2}{c}{ Correlations } \\
& \multicolumn{1}{c}{$\begin{array}{c}\text { KualitasPelay } \\
\text { anan }\end{array}$} & $\begin{array}{c}\text { KeputusanPe } \\
\text { mbelian }\end{array}$ \\
\hline KualitasPelayanan & Pearson Correlation & 1 & $.395^{* *}$ \\
\cline { 2 - 4 } & Sig. (2-tailed) & & .000 \\
\cline { 2 - 4 } & $\mathrm{N}$ & 100 & 100 \\
\hline KeputusanPembelian & Pearson Correlation & $.395^{* *}$ & 1 \\
\cline { 2 - 4 } & Sig. (2-tailed) & .000 & \\
\cline { 2 - 4 } & $\mathrm{N}$ & 100 & 100 \\
\hline$* *$ Correlation is significant at the 0.01 level (2-tailed).
\end{tabular}

Gambar 5. Hasil Uji Korelasi Parsial X2

Berdasarkan Gambar 5, nilai koefisien korelasi antara kualitas pelayanan dan keputusan pembelian adalah 0,395. Maka dapat disimpulkan bahwa kualitas pelayanan dan keputusan pembelian memiliki hubungan yang rendah.

\section{Uji Multikolinearitas}

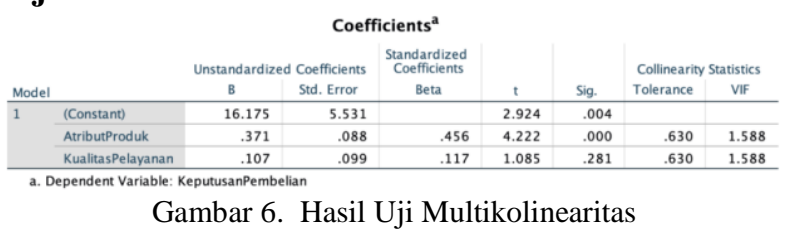

Berdasarkan hasil uji multikolinearitas seperti ditunjukkan pada gambar 6 , nilai tolerance yang diperoleh adalah sebesar 0,630 dan Nilai VIF sebesar 1,588. Maka dari hasil tersebut, dapat disimpulkan bahwa tidak terjadi multikolinearitas dalam penelitian ini.

\section{Analisis Regresi Linier Berganda}

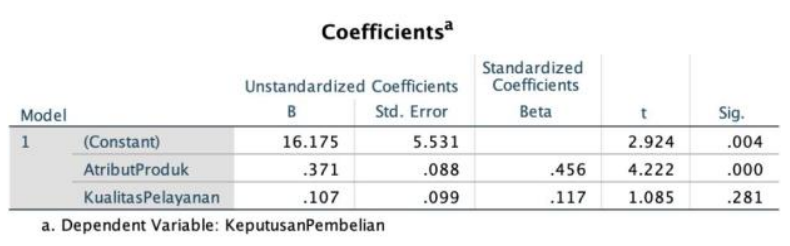

Gambar 7. Hasil Analisis Linier Berganda

Berdasarkan gambar $7 \mathrm{di}$ atas, persamaan regresi linier berganda pada penelitian ini adalah sebagai berikut :

$$
y=16,175+0,371 X 1+0,107 X 2
$$

Dapat diartikan bahwa:

1. Jika atribut produk (X1) dan kualitas pelayanan (X2) bernilai 0 satuan, maka keputusan pembelian adalah sebesar 16,175 satuan.

2. Jika terdapat peningkatan atribut produk sebesar 1 satuan, maka keputusan pembelian akan meningkat sebesar 0,371 satuan dengan asumsi nilai variabel lain tetap.

3. Jika terdapat peningkatan kualitas pelayanan sebesar 1 satuan, maka keputusan pembelian 
akan meningkat sebesar 0,107 satuan dengan asumsi nilai variabel lain tetap.

Koefisien regresi bernilai positif, maka atribut produk dan kualitas pelayanan memberi pengaruh positif terhadap keputusan pembelian. Variabel atribut produk memiliki nilai koefisien sebesar 0,371 dan variabel kualitas pelayanan memiliki nilai koefisien sebesar 0,107. Dapat disimpulkan bahwa atribut produk memiliki pengaruh lebih besar terhadap keputusan pembelian dibandingkan dengan kualitas pelayanan.

\section{Uji Hipotesa Parsial (Uji T)}

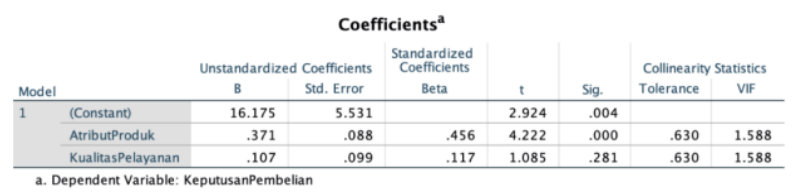

Gambar 8. Hasil Uji T

Gambar 8 menunjukkan hasil pengolahan data untuk uji T. Nilai thitung adalah sebesar 1,984 $(\alpha=5 \%, \mathrm{df}=98)$. Nilai t tabel untuk atribut produk (X1) sebesar 4,222 dan memiliki nilai signifikansi sebesar 0,00. Maka disimpulkan bahwa atribut produk berpengaruh secara parsial terhadap keputusan pembelian konsumen Ohayou Bandung. Nilai t tabel untuk kualitas pelayanan (X2) menunjukkan angka 1.085 dengan nilai signifikansi 0,281 yang diartikan bahwa kualitas pelayanan tidak berpengaruh secara parsial terhadap keputusan pembelian konsumen Ohayou Bandung. Dapat disimpulkan bahwa konsumen lebih mengutamakan atribut produk dibanding kualitas pelayanan sehingga meningkatkan kualitas pelayanan saja tidak cukup untuk meningkatkan keputusan pembelian.

\section{Uji Hipotesa Simultan (Uji F)}

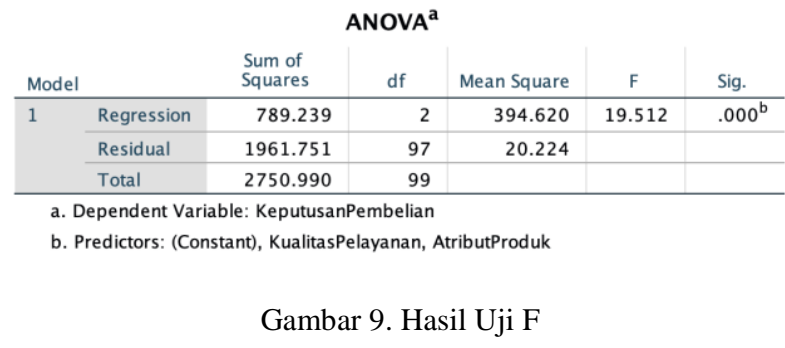

Gambar 9 menunjukkan besar nilai signifikansi uji $\mathrm{F}$ berdasarkan tabel Anova. hasil tersebut menunjukkan bahwa besar nilai signifikansi adalah 0,00 . Besaran tersebut menunjukkan bahwa H0 ditolak karena nilai tersebut lebih kecil dari 0,05 dapat diartikan bahwa terdapat pengaruh secara simultan pada atribut produk dan kualitas pelayanan terhadap keputusan pembelian konsumen Ohayou Bandung.

\section{Uji Koefisien Determinasi}

\begin{tabular}{|c|c|c|c|c|}
\hline \multicolumn{5}{|c|}{ Model Summaryb } \\
\hline Model & $\mathrm{R}$ & R Square & $\begin{array}{l}\text { Adjusted R } \\
\text { Square }\end{array}$ & $\begin{array}{l}\text { Std. Error of } \\
\text { the Estimate }\end{array}$ \\
\hline 1 & $.536^{\mathrm{a}}$ & .287 & .272 & 4.49714 \\
\hline
\end{tabular}

Gambar 10. Hasil Uji Koefisien Determinasi

Berdasarkan gambar 8 di atas diperoleh bahwa besar nilai $R$ Square adalah 0,287 sehingga nilai koefisien determinasi sebesar 28,7\%. Hal ini menunjukkan bahwa atribut produk (X1) dan kualitas pelayanan (X2) mempengaruhi keputusan pembelian sebesar $28,7 \%$, sedangkan $71,3 \%$ lainnya dipengaruhi faktor lain yang tidak diteliti dalam penelitian ini.

\section{KESIMPULAN}

1. Variabel atribut produk dikategorikan baik dengan persentase sebesar 79,4\%. Untuk meningkatkan atribut produk, Ohayou perlu memperhatikan fitur produk seperti variasi menu (baik kopi maupun non kopi) dan menyediakan fasilitas yang memadai. Di samping itu, peningkatan tampilan kemasan agar lebih menarik dan tidak mudah rusak perlu dilakukan Ohayou agar konsumen lebih puas dan dapat dijadikan alat branding untuk Ohayou.

Variabel pelayanan merupakan variable dengan penilaian responden tertinggi di mana mencapai angka $84,6 \%$ yang berarti dinilai sangat baik oleh responden. Perusahaan dapat meningkatkan pelayanan antara lain melalui memberikan training bagi pegawai agar dapat mengetahui kebutuhan konsumen, dan mampu memberikan pelayanan dengan cepat tanggap. Di samping itu, pegawai perlu dilatih agar dapat memberikan empati yang sesuai dengan karakteristik konsumen. Empati menurut 
Lupiyoadi dalam Rizgy, Warso \& Fathoni (2016) adalah perhatian tulus pegawai kepada konsumen. Hal ini dapat dilakukan pegawai dengan berupaya mendekatkan diri pada konsumen sehingga keperluan, keinginan dan kebutuhan konsumen dapat segera diketahui dan dipenuhi oleh karyawan. Hal ini dapat meningkatkan kualitas pelayanan di mata konsumen dan pada akhirnya dapat meningkatkan hubungan konsumen dengan kedai kopi Ohayou .

Variabel proses keputusan pembelian memperoleh persentase sebesar 78,3\%, di mana mayoritas responden menilai baik proses keputusannya membeli produk Ohayou. Adapun keputusan pembelian membeli produk Ohayou dinilai sangat baik oleh responden.

Adapun beberapa hal yang dapat dilakukan oleh Ohayou untuk meningkatkan proses keputusan pembelian konsumen antara lain : meningkatkan fasilitas yang disediakan Ohayou, hal ini dikarenakan rata-rata penilaian responden atas indicator ini paling rendah di dalam dimensi Pengenalan Masalah. Di samping itu, responden kesulitan untuk mendapatkan informasi Ohayou di social media (indicator ini dinilai kurang baik oleh responden). Oleh sebab itu, Ohayou perlu meningkatkan brandingnya melalui social media. Di samping itu, banyaknya kedai kopi di sekitar Ciumbuleuit menyebabkan konsumen mudah beralih ke kedai kopi lain. Ohayou perlu meningkatkan atribut produk dan pelayanannya agar dapat memuaskan konsumen dan dapat lebih unggul dibandingkan pesaingnya.

2. Berdasarkan hasil dari persamaan analisis linier berganda, variabel atribut produk memiliki nilai koefisien sebesar 0,371 dan variabel kualitas pelayanan memiliki nilai koefisien sebesar 0,107. Dapat disimpulkan bahwa atribut produk memiliki pengaruh lebih besar terhadap keputusan pembelian daripada kualitas pelayanan.

3. Berdasarkan uji hipotesa parsial atau uji $\mathrm{T}$, variable atribut produk memiliki pengaruh parsial terhadap keputusan pembelian sedangkan kualitas pelayanan tidak memiliki pengaruh parsial terhadap keputusan pembelian. Dari hasil tersebut, dapat disimpulkan bahwa konsumen lebih mengutamakan atribut produk dibandingkan kualitas pelayanan. Hal ini cukup menarik karena responden memberikan nilai yang cukup tinggi terhadap kualitas pelayanan Ohayou (sangat baik) namun hal ini tidak berpengaruh terhadap keputusan pembeliannya. Hal ini sesuai dengan hasil rekapitulasi penilaian responden di mana penilaian "sangat baik" hanya dimiliki oleh kualitas pelayanan, namun tidak pada variabel atribut produk dan keputusan pembelian. Oleh sebab itu, perusahaan perlu meningkatkan atribut produk yang memiliki pengaruh terhadap keputusan pembelian di Ohayou.

4. Berdasarkan uji koefisien determinasi, atribut produk dan kualitas pelayanan memiliki pengaruh sebesar $28,7 \%$ terhadap keputusan pembelian di Ohayou. Sedangkan sisanya, yaitu $71,3 \%$ dipengaruhi oleh faktor lain yang tidak termasuk dalam penelitian ini, seperti harga, promosi, word of mouth, dan sebagainya. Penelitian selanjutnya dapat meneliti faktorfaktor lain yang mempengaruh keputusan pembelian.

\section{DAFTAR PUSTAKA}

Aji, F., \& Semuel, H. (2015). ANALISA PENGARUH BRAND IDENTITY TERHADAP BRAND AWARENESS DAN BRAND. Jurnal Strategi Pemasaran, 3(1), 1-10. Retrieved from http://publication.petra.ac.id/index.php/m anajemenpemasaran/article/view/3646/3314

Crawford, M., \& Benedetto, A. D. (2011). New Products Management (10th International ed.). New York: McGrawHill.

Ghozali, I. (2016). Aplikasi Analisis Multivariate Dengan Program SPSS 23. Badan Peneliti Universitas Diponogoro.

Kotler, P., \& Keller, K. L. (2016). Marketing Management 15ed. Pearson Education Limited.

Kotler, P., Armstrong, G., \& Opresnik, M. (2018). Principles of Marketing 17ed. Pearson Education Limited. 
Kotler, P., Kartajaya, H., \& Setiawan, I. (2016). Marketing 4.0: Moving from traditional to digital. Retrieved from https://books.google.com/books?hl=en\&lr $=\& \mathrm{id}=\mathrm{jN} 9 \mathrm{mDQAAQBAJ} \&$ oi $=$ fnd $\& p g=P$ R13\&dq=philip+kotler\&ots=nyy8hW6aY c\&sig=vPLXJ3qtPIhhZy8SO2oqDtvj-fE

McLeod, S. (2019). variables. Retrieved from simplypsychology:

https://www.simplypsychology.org/variab les.html

Nazah, I. S., Hartati, T., \& Siambaton, E. (2017, April). PENGARUH ATRIBUT PRODUK. Epigram, 14(1), 51-58.

Priyatno, D. (2018). SPSS Panduan Mudah Olah Data Bagi Mahasiswa Dan Umum. Penerbit Andi.

Rizqy, R., Warso, M., \& Fathoni, A. (2016). PENGARUH KUALITAS PELAYANAN TERHADAP KEPUASAN. Journal Of Management, 2(2). doi:https://jurnal.unpand.ac.id/index.php/ MS/article/view/497/483

Soenawan, A., Malonda, E., \& Aprilia, A. (2015). PENGARUH KUALITAS PRODUK, KUALITAS PELAYANAN DAN HARGA TERHADAP KEPUTUSAN PEMBELIAN KONSUMEN D'STUPID BAKER SPAZIO GRAHA FAMILY SURABAYA. Jurnal Hospitality Dan Manajemen Jasa, 3(2), 395-409. Retrieved from http://publication.petra.ac.id/index.php/m anajemenperhotelan/article/viewFile/3547/3216

Sugianto, D. (2019). Hasil Riset : Kedai Kopi di RI Bertambah 2.000 Dalam 3 Tahun. Retrieved 2020, from Detikfinance: https://finance.detik.com/berita-ekonomibisnis/d-4826275/hasil-riset-kedai-kopidi-ri-bertambah-2000-dalam-3-tahun

Sugiyono. (2016). Metode Penelitian Kuantitatif, Kualitatif, dan $R \& D$. Alfabeta.

Sugiyono. (2019). Metode Penelitian Kuantitatif, Kualitatif, dan $R \& D$. Alfabeta.

Sumaryati, M., \& Gregie, G. (2016). ANALISIS ATRIBUT PRODUK TERHADAP PERILAKU PEMBELIAN KONSUMEN
SEPATU MEREK NIKE. Jurnal Manajemen, 13 (1), 58-75. Retrieved from http://ojs.atmajaya.ac.id/index.php/JM/arti cle/view/601 